Supporting Information

for

\title{
AEROBIC ALCOHOL OXIDATION WITH A CATIONIC PALLADIUM COMPLEX: INSIGHTS INTO CATALYST DESIGN AND DECOMPOSITION
}

Nicholas R. Conley, Liezel A. Labios, David M. Pearson, Charles McCrory, and Robert M. Waymouth*

Department of Chemistry, Stanford University, Stanford, California 94305-5080

\section{Table of Contents}

I. Experimental procedures, S2-S5

II. ${ }^{1} \mathrm{H}$ and ${ }^{13} \mathrm{C}$ NMR spectra, S6-S16

III. Thermodynamic data for 1, S17-S22

IV. Electrochemical detection of hydrogen peroxide, S23-S25

V. Conversion of $\mu$-hydroxo Pd dimer $\mathbf{4}$ to $\mathbf{1}$ using acetic acid, S26

VI. Conversion of 1 to $\mu$-hydroxo Pd dimer 4 using water, S27

VII. References, S28 


\section{Experimental procedures}

Synthesis of [(2,9-dimethyl-1,10-phenanthroline)Pd( $\boldsymbol{\mu}$-OAc) $]_{\mathbf{2}}(\text { OTf })_{\mathbf{2}}(\mathbf{1})$. To a $25 \mathrm{ml}$ RB flask with stirbar was added 2 (0.0400 g, $0.0924 \mathrm{mmol}), 3$ (0.0642 g, $0.0924 \mathrm{mmol})$, and acetonitrile $(10.0 \mathrm{ml})$. The resulting mixture was stirred until all solids dissolved and then precipitated with diethyl ether to give an orange solid. This solid was isolated by centrifugation, washed with diethyl ether, and dried under vacuum to give $\mathbf{1}$ as an orange solid (0.0589 g, $0.0563 \mathrm{mmol}, 61 \%$ yield). ${ }^{1} \mathrm{H} \mathrm{NMR}\left(300 \mathrm{MHz}, \mathrm{CD}_{3} \mathrm{CN}\right.$, satd. soln. to favor dimer), dimer peaks: $\delta 2.22(\mathrm{~s}, 6 \mathrm{H}), 2.59(\mathrm{~s}, 12 \mathrm{H}), 7.36(\mathrm{~d}, 4 \mathrm{H}, J=8.4 \mathrm{~Hz}), 7.66(\mathrm{~s}$, $4 \mathrm{H}), 8.24(\mathrm{~d}, 4 \mathrm{H}, J=8.4 \mathrm{~Hz}) ;{ }^{1} \mathrm{H}$ NMR $\left(500 \mathrm{MHz}, \mathrm{CD}_{3} \mathrm{CN}, 7.2 \mathrm{mM}\right.$ soln. $)$, monomer peaks: $\delta 1.98(\mathrm{~s}, 3 \mathrm{H}), 2.80(\mathrm{~s}, 6 \mathrm{H}), 7.71(\mathrm{~d}, 2 \mathrm{H}, J=9.5 \mathrm{~Hz}), 8.01(\mathrm{~s}, 2 \mathrm{H}), 8.59(\mathrm{~d}, 2 \mathrm{H}, 8$ $\mathrm{Hz}) ;{ }^{13} \mathrm{C}$ NMR (75 MHz, $\mathrm{CD}_{3} \mathrm{CN}$, satd. soln. to favor dimer): $\delta 23.77,24.73,128.02$, 128.99, 129.10, 141.29, 146.92, 166.68, 188.56, $\mathrm{CF}_{3} \mathrm{SO}_{3}{ }^{-}$not observed; ESI-MS: $\mathrm{m} / \mathrm{z}$ (relative intensity) [ion] $374(75 \%)\left[0.5 \mathrm{M}-\mathrm{CF}_{3} \mathrm{SO}_{3}{ }^{-}+\mathrm{H}^{+}, 314(47 \%)\left[0.5 \mathrm{M}-\mathrm{CF}_{3} \mathrm{SO}_{3}\right.\right.$ $\left.-\mathrm{CH}_{3} \mathrm{COO}^{-}\right]^{+}, 209(100 \%)\left[0.5 \mathrm{M}-\mathrm{CF}_{3} \mathrm{SO}_{3}{ }^{-}-\mathrm{CH}_{3} \mathrm{COO}^{-}-\mathrm{Pd}^{2+}+\mathrm{H}^{+}\right]^{+}$. Anal. Calcd for $\mathrm{C}_{34} \mathrm{H}_{30} \mathrm{~N}_{4} \mathrm{O}_{10} \mathrm{~S}_{2} \mathrm{Pd}_{2} \mathrm{~F}_{6}$ (1045.59): C, 39.06; H, 2.89; N, 5.36; Pd, 20.36. Found: C, 39.14; $\mathrm{H}, 2.87$; N, 5.22; Pd, 20.1.

Synthesis of (2,9-dimethyl-1,10-phenanthroline) $P d(O A c)_{2}(2)$. This compound was prepared as previously reported. ${ }^{1}$

Synthesis of (2,9-dimethyl-1,10-phenanthroline)Pd(MeCN $)_{2}(\mathrm{OTf})_{2}(3)$. To a slurry of $2(0.221 \mathrm{~g}, 0.511 \mathrm{mmol})$ in acetonitrile $(1.0 \mathrm{ml})$ was added a solution of triflic acid in acetonitrile $(0.33 \mathrm{M}, 3.8 \mathrm{ml}, 2.5$ eq. $)$. The solution was stirred briefly and then precipitated with diethyl ether to give a yellow solid. This solid was isolated by centrifugation, precipitated two more times from acetonitrile using diethyl ether, and dried under vacuum to give 3 as a light yellow solid $(0.090 \mathrm{~g})$. Additional triflic acid $(0.33 \mathrm{M}, 1.0 \mathrm{ml})$ was added to the original supernatant, followed by brief stirring and precipitation with diethyl ether. The resulting yellow solid was subjected to the same workup as described above to give additional $\mathbf{3}(0.021 \mathrm{~g})$. The pure solids were combined $\left(0.111 \mathrm{~g}, 0.160 \mathrm{mmol}, 31 \%\right.$ yield). ${ }^{1} \mathrm{H}$ NMR $\left(300 \mathrm{MHz}, \mathrm{CD}_{3} \mathrm{CN}\right): \delta 2.98(\mathrm{~s}$, $6 \mathrm{H}), 7.77(\mathrm{~d}, 2 \mathrm{H}, J=8.4 \mathrm{~Hz}), 8.07(\mathrm{~s}, 2 \mathrm{H}), 8.68(\mathrm{~d}, 4 \mathrm{H}, J=8.4 \mathrm{~Hz}) ;{ }^{1} \mathrm{H}$ NMR $(400 \mathrm{MHz}$, DMSO-d $\left.d_{6}\right): \delta 2.06\left(\mathrm{~s}, 6 \mathrm{H}, \mathrm{CH}_{3} \mathrm{CN}\right), 3.09(\mathrm{~s}, 6 \mathrm{H}), 7.90(\mathrm{~d}, 2 \mathrm{H}, J=8.4 \mathrm{~Hz}), 8.17(\mathrm{~s}, 2 \mathrm{H})$, $8.80(\mathrm{~d}, 2 \mathrm{H}, J=8.4 \mathrm{~Hz}) ;{ }^{13} \mathrm{C}$ NMR $\left(125 \mathrm{MHz}, \mathrm{DMSO}-d_{6}\right): \delta 1.19,24.85,118.15,120.70$ (q, $J=320.1 \mathrm{~Hz}, C_{3} \mathrm{SO}_{3}{ }^{-}$), 126.72, 127.42, 128.52, 140.16, 146.40, 164.65; ESI-MS: $\mathrm{m} / \mathrm{z}$ (relative intensity) [ion] $209(100 \%)\left[\mathrm{M}-\mathrm{Pd}^{2+}-2 \mathrm{CF}_{3} \mathrm{SO}_{3}{ }^{-}+\mathrm{H}^{+}\right]^{+}, 315(6 \%)[\mathrm{M}-$ $\left.2 \mathrm{CF}_{3} \mathrm{SO}_{3}{ }^{-}+\mathrm{H}\right]^{+}, 149(100 \%)\left[\mathrm{CF}_{3} \mathrm{SO}_{3}{ }^{-}\right]$. Anal Calcd for $\mathrm{C}_{20} \mathrm{H}_{18} \mathrm{O}_{6} \mathrm{~N}_{4} \mathrm{~S}_{2} \mathrm{PdF}_{6}$ (694.92): $\mathrm{C}$, 34.57; H, 2.61; N, 8.06; Pd, 15.3. Found: C, 34.81; H, 2.68; N, 8.77; Pd, 14.6.

\section{Synthesis of (2,9-dimethyl-1,10-phenanthroline)Pd( $\mu-\mathrm{OH})]_{2}(\mathrm{OTf})_{2}(4)$ from 1 and} water. A concentrated solution of $1(100 \mathrm{mg}, 0.095 \mathrm{mmol})$ in acetonitrile $(4 \mathrm{ml})$ was prepared and then the solution was diluted by addition of an equal volume of $\mathrm{H}_{2} \mathrm{O}$, causing the orange solution to become yellow and cloudy. The solution was stirred for 1 $\mathrm{h}$ and the precipitate was isolated by centrifugation. The pellet was washed with acetonitrile and dried under vacuum, yielding the dimer $\mathbf{4}$ as a yellow solid $(23.0 \mathrm{mg}$, $25 \%$ yield). ${ }^{1} \mathrm{H}$ NMR (300 MHz, DMSO- $\left.d_{6}\right): \delta 2.13(\mathrm{~s}, 2 \mathrm{H}), 2.87(\mathrm{~s}, 12 \mathrm{H}), 7.86(\mathrm{~d}, 4 \mathrm{H}, J$ 
$=8.1 \mathrm{~Hz}), 8.15(\mathrm{~s}, 4 \mathrm{H}), 8.79(\mathrm{~d}, 4 \mathrm{H}, J=8.1 \mathrm{~Hz}) ;{ }^{13} \mathrm{C}$ NMR $\left(500 \mathrm{MHz}, \mathrm{DMSO}-d_{6}\right): \delta$ 23.12, 126.72, 127.92, 128.26, 139.86, 146.10, 165.14, $\mathrm{CF}_{3} \mathrm{SO}_{3}{ }^{-}$not observed; ESI-MS: $\mathrm{m} / \mathrm{z}$ (relative intensity) [ion] $372(100 \%)\left[0.5 \mathrm{M}-\mathrm{CF}_{3} \mathrm{SO}_{3}{ }^{-}+\mathrm{CH}_{3} \mathrm{CN}\right]^{+}, 314(30 \%)[0.5 \mathrm{M}$ $\left.-\mathrm{CF}_{3} \mathrm{SO}_{3}{ }^{-}-\mathrm{OH}^{-}\right]^{+}, 209(50 \%)\left[0.5 \mathrm{M}-\mathrm{CF}_{3} \mathrm{SO}_{3}{ }^{-}-\mathrm{HO}^{-}-\mathrm{Pd}^{2+}+\mathrm{H}^{+}\right]^{+}$. Anal. Calcd for $\mathrm{C}_{30} \mathrm{H}_{26} \mathrm{~N}_{4} \mathrm{Pd}_{2} \mathrm{O}_{8} \mathrm{~S}_{2} \mathrm{~F}_{6}$ (961.51): C, 37.47; H, 2.73; N, 5.83; Pd, 22.1. Found: C, 37.27; H, $2.61 ; \mathrm{N}, 5.89 ; \mathrm{Pd}, 22.0$.

Synthesis of (2,9-dimethyl-1,10-phenanthroline) $\mathrm{Pd}(\mu-\mathrm{OH})]_{2}(\mathrm{OTf})_{2}(4),(9-$-methyl1,10-phenanthroline-2-carboxylate)Pd(OTf) (5), and [(9-methyl-1,10-phenanthrolin2-yl)methanolate]Pd(OTf) (6) from 1 and $30 \%$ hydrogen peroxide. In a test tube, 9.79 $\mathrm{M}(\sim 30 \%)$ hydrogen peroxide $(73.2 \mu \mathrm{L}, 0.717 \mathrm{mmol}, 15.0$ eq.) was added to a solution of $1(0.0500 \mathrm{~g}, 0.0478 \mathrm{mmol})$ in acetonitrile $(2.0 \mathrm{~mL})$ with stirring. The solution immediately, albeit temporarily, changed color from yellow to deep red and bubbling was observed. After 15 minutes of stirring in air, the solution had become bright yellow in color and contained a light yellow precipitate. This precipitate was isolated from the reaction mixture by centrifugation, washed with acetonitrile, and dried under vacuum to give 4 as a pale yellow solid $(0.016 \mathrm{~g}, 0.017 \mathrm{mmol})$. The supernatant was then filtered and precipitated with diethyl ether $(\sim 2 \mathrm{ml})$. The resulting yellow solid was isolated by centrifugation, precipitated a second time from acetonitrile, washed with diethyl ether, and dried under vacuum to give 6 as a bright yellow solid $(0.010 \mathrm{~g}, 0.019 \mathrm{mmol})$. The supernatants from both precipitations of $\mathbf{6}$ were combined, filtered, and evaporated to give 5 as an orange solid $(0.0011 \mathrm{~g}, 0.0021 \mathrm{mmol})$.

Alternative synthesis of (9-methyl-1,10-phenanthroline-2-carboxylate)Pd(OTf) (5) by aerobic oxidation of 2-heptanol. 2-Heptanol (1.14 $\mathrm{mL}, 8.04 \mathrm{mmol})$ was added to a solution of 1 ( $0.1256 \mathrm{~g}, 0.1201 \mathrm{mmol})$ in acetonitrile $(8.0 \mathrm{~mL})$. The dark orange reaction mixture was stirred vigorously in air overnight and became light yellow-orange in color. After filtration, a light orange solid was precipitated from the filtrate using diethyl ether. This solid was isolated by centrifugation, precipitated a second time from acetonitrile, washed with diethyl ether, and dried under vacuum to give $\mathbf{5}$ as a light orange solid $(0.027 \mathrm{~g}, 0.051 \mathrm{mmol}, 42 \%$ yield $)$.

Characterization of (9-methyl-1,10-phenanthroline-2-carboxylate)Pd(MeCN)(OTf) (5). ${ }^{1} \mathrm{H}$ NMR (300 MHz, $\left.\mathrm{CD}_{3} \mathrm{CN}\right): \delta 2.87(\mathrm{~s}, 3 \mathrm{H}), 7.91(\mathrm{~d}, 1 \mathrm{H}, J=8.4 \mathrm{~Hz}), 8.01(\mathrm{~d}, 1 \mathrm{H}, J$ $=8.7 \mathrm{~Hz}), 8.12(\mathrm{~d}, 1 \mathrm{H}, J=9.0 \mathrm{~Hz}), 8.21(\mathrm{~d}, 1 \mathrm{H}, J=8.7 \mathrm{~Hz}), 8.69(\mathrm{~d}, 1 \mathrm{H}, J=8.7 \mathrm{~Hz})$, $8.89(\mathrm{~d}, 1 \mathrm{H}, J=8.1 \mathrm{~Hz}) ;{ }^{13} \mathrm{C}$ NMR $\left(300 \mathrm{MHz}, \mathrm{CD}_{3} \mathrm{CN}\right): \delta 27.08,125.58,126.89,130.27$, $130.41,131.23,132.51,141.69,142.29,145.75,148.08,150.02,166.77,172.16, \mathrm{CF}_{3} \mathrm{SO}_{3}$ not observed; ESI-MS: $m / z$ (relative intensity) [ion] $384(10 \%)\left[\mathrm{M}-\mathrm{CF}_{3} \mathrm{SO}_{3}{ }^{-}\right]^{+}, 345$ (22\%) $\left[\mathrm{M}-\mathrm{CF}_{3} \mathrm{SO}_{3}{ }^{-}-\mathrm{CH}_{3} \mathrm{CN}\right]^{+}, 299(100 \%)\left[\mathrm{M}-\mathrm{CF}_{3} \mathrm{SO}_{3}{ }^{-}-\mathrm{CH}_{3} \mathrm{CN}-\mathrm{COO}^{-}\right]^{+}, 195$ (20\%) $\left[\mathrm{M}-\mathrm{CF}_{3} \mathrm{SO}_{3}{ }^{-}-\mathrm{CH}_{3} \mathrm{CN}-\mathrm{CO}_{2}-\mathrm{Pd}^{2+}\right]^{+}$. Anal. Calcd for $\mathrm{C}_{17} \mathrm{H}_{12} \mathrm{~N}_{3} \mathrm{PdO}_{5} \mathrm{SF}_{3}$ (533.78): C, 38.25; H, 2.27; N, 7.87; Pd, 19.9. Found: C, 38.15; H, 2.19; N, 7.77; Pd, 20.2 .

Characterization of [(9-methyl-1,10-phenanthrolin-2-yl)methanolate]Pd(MeCN) (OTf) (6). ${ }^{1} \mathrm{H}$ NMR (500 MHz, DMSO-d $\left.{ }_{6}\right): \delta 2.06(\mathrm{~s}, 3 \mathrm{H}), 5.24(\mathrm{~s}, 2 \mathrm{H}), 7.67(\mathrm{~d}, 1 \mathrm{H}, J=$ $8.5 \mathrm{~Hz}), 7.77(\mathrm{~d}, 1 \mathrm{H}, J=8.5 \mathrm{~Hz}), 7.86(\mathrm{~d}, 1 \mathrm{H}, J=9.0 \mathrm{~Hz}), 7.88(\mathrm{~d}, 1 \mathrm{H}, J=8.5 \mathrm{~Hz}), 8.47$ 
$(\mathrm{d}, 1 \mathrm{H}, J=8.0 \mathrm{~Hz}), 8.65(\mathrm{~d}, 1 \mathrm{H}, J=8.5 \mathrm{~Hz}) ;{ }^{1} \mathrm{H} \mathrm{NMR}\left(300 \mathrm{MHz}, \mathrm{CD}_{3} \mathrm{CN}\right): \delta 2.91(\mathrm{~s}$, $3 \mathrm{H}), 5.35(\mathrm{~s}, 2 \mathrm{H}), 7.82(\mathrm{~d}, 1 \mathrm{H}, J=8.7 \mathrm{~Hz}), 7.83(\mathrm{~d}, 1 \mathrm{H}, J=8.7 \mathrm{~Hz}), 8.10(\mathrm{~d}, 2 \mathrm{H}, J=0.9$ $\mathrm{Hz}), 8.61(\mathrm{~d}, 1 \mathrm{H}, J=8.4 \mathrm{~Hz}), 8.76(\mathrm{~d}, 1 \mathrm{H}, J=8.4 \mathrm{~Hz}) ;{ }^{13} \mathrm{C}$ NMR $\left(500 \mathrm{MHz}\right.$, DMSO- $\left.d_{6}\right)$ : $\delta 1.18,23.57,74.63,118.14,120.70\left(\mathrm{q}, J=320.6 \mathrm{~Hz}, C F_{3} \mathrm{SO}_{3}{ }^{-}\right), 123.81,126.05,127.54$, 127.67, 128.62, 128.66, 139.21, 140.02, 142.82, 144.84, 150.91, 164.59; ESI-MS: $\mathrm{m} / z$ (relative intensity) [ion] $329(28 \%)\left[\mathrm{M}-\mathrm{CF}_{3} \mathrm{SO}_{3}{ }^{-}-\mathrm{CH}_{3} \mathrm{CN}\right]^{+}, 299(100 \%)\left[\mathrm{M}-\mathrm{CF}_{3} \mathrm{SO}_{3}{ }^{-}\right.$ $\left.-\mathrm{CH}_{3} \mathrm{CN}-\mathrm{CH}_{2} \mathrm{O}\right]^{+}, 223(10 \%)\left[\mathrm{M}-\mathrm{CF}_{3} \mathrm{SO}_{3}{ }^{-}-\mathrm{CH}_{3} \mathrm{CN}-\mathrm{Pd}^{2+}\right]^{+}$. HRMS (ESI) calcd for $\mathrm{C}_{14} \mathrm{H}_{11} \mathrm{~N}_{2} \mathrm{PdO}^{+}\left[\mathrm{M}-\mathrm{CF}_{3} \mathrm{SO}_{3}{ }^{-}-\mathrm{CH}_{3} \mathrm{CN}\right]^{+}$, required $\mathrm{m} / \mathrm{z}$ 328.9906, found, 328.9910 .

Conditions for crystallization of $\mathbf{1 , 4}$, and 5. Crystallization of 1 was achieved by diffusion of ether vapor into a saturated solution of $\mathbf{1}$ in acetonitrile. High quality crystals were obtained in less than 30 min. Crystallization of $\mathbf{4}$ was effected by vapor diffusion of dichloromethane into a solution of $\mathbf{4}$ in dimethylsulfoxide. Due to its asymmetry, crystallization of $\mathbf{5}$ proved to be much more difficult and a large number of vapor diffusion conditions failed. Suitable crystals were finally obtained by slow evaporation of an acetonitrile solution of $\mathbf{5}$.

Protocol for aerobic alcohol oxidation of 2-heptanol using 1 or 3. To a $25 \mathrm{ml}$ roundbottom flask with stirbar was added acetonitrile $(2.0 \mathrm{ml}), 2$-heptanol $(142.2 \mu \mathrm{L}, 1.000$ mmol), and optionally, $n$-decane $(100.0 \mu \mathrm{L}, 0.5130 \mathrm{mmol}$, int. std.). The mixture was stirred until the $n$-decane dissolved completely, and an aliquot was collected at $t=0$ for analysis by GC (gas chromatography). The catalyst ( $0.03 \mathrm{~mol} \% \mathrm{Pd}$ ) was added and the reaction mixture was stirred vigorously at room temperature under a balloon of air. During the reaction, aliquots were collected, quenched by dilution into acetonitrile, and subjected to GC analysis.

Protocol for aerobic alcohol oxidation of 2-heptanol using 2. The above procedure was followed, with the exception that acetonitrile/dichloromethane (1:1) was used as the solvent $(2.0 \mathrm{ml})$.

Protocol for aerobic alcohol oxidation of 2-heptanol using 4. The above procedure was followed, with the exception that acetonitrile/dimethylsulfoxide (1:1) was used as the solvent $(2.0 \mathrm{ml})$.

Conditions for GC separation. An Alltech EC-WAX GC column (30 m, 0.53 mm ID, $1.00 \mu \mathrm{m}$ film) was employed for all separations using the following conditions: column head pressure, $100 \mathrm{kPa}$ (14.5 psig) helium; initial column temp., $70{ }^{\circ} \mathrm{C}$; initial hold time, $0 \mathrm{~min}$; rate of temp. ramp, $20{ }^{\circ} \mathrm{C} / \mathrm{min}$; final temp., $150{ }^{\circ} \mathrm{C}$; final hold time, $0 \mathrm{~min}$; injection temp., $225{ }^{\circ} \mathrm{C}$; detector temp. $225^{\circ} \mathrm{C}$. The effluent was combusted in a $\mathrm{H}_{2} / \mathrm{O}_{2}$ flame and detected using an FID (flame ionization detector). Ion count data were sent to a plotter, which integrated the area under the peaks.

Determination of reaction progress. The reaction progress was determined by use of either (a) an internal standard method or (b) a ratiometric method.

a. Internal standard method 
The response factor $(\mathrm{RF})$ for the 2-heptanone/ $n$-decane (internal standard) combination was determined using the following equation:

$$
\mathrm{RF}=\left(\text { area }_{\mathrm{IS}} \times \text { amount }_{\text {ketone }}\right) /\left(\text { amount }_{\mathrm{IS}} \times \text { area }_{\text {ketone }}\right),
$$

where IS is the internal standard. The amount of the 2-heptanone present in the reaction mixture at any given time could then be calculated using the following equation:

$$
\text { amount }_{\text {ketone }}=\left(\mathrm{RF} \times \text { amount }_{\mathrm{IS}} \times \text { area }_{\text {ketone }}\right) /\left(\text { area }_{\mathrm{IS}}\right)
$$

\section{b. Ratiometric method}

In the aerobic oxidation of 2-heptanol, it was found that the percent yield could also be determined using a ratiometric method, shown by the following equation:

$$
\% \text { yield }=\left[\operatorname{area}_{2-\text { heptanone }} /\left(\operatorname{area}_{2-\text { heptanone }}+\operatorname{area}_{2-\text { heptanol }}\right)\right] \times 100 . \quad(\text { Eqn. 3) }
$$

This equation is valid because (1) 2-heptanol is converted only to 2-heptanone and (2) equimolar amounts of 2-heptanol and 2-heptanone produce the same FID response. The validity of this equation was verified using the internal standard method. In cases where the secondary alcohol and its corresponding ketone produce different detector responses, it is necessary to account for this using a response factor.

The ratiometric method is not suitable for primary alcohols, such as 1-heptanol, because such alcohols can be oxidized to carboxylic acids. ${ }^{2}$ 


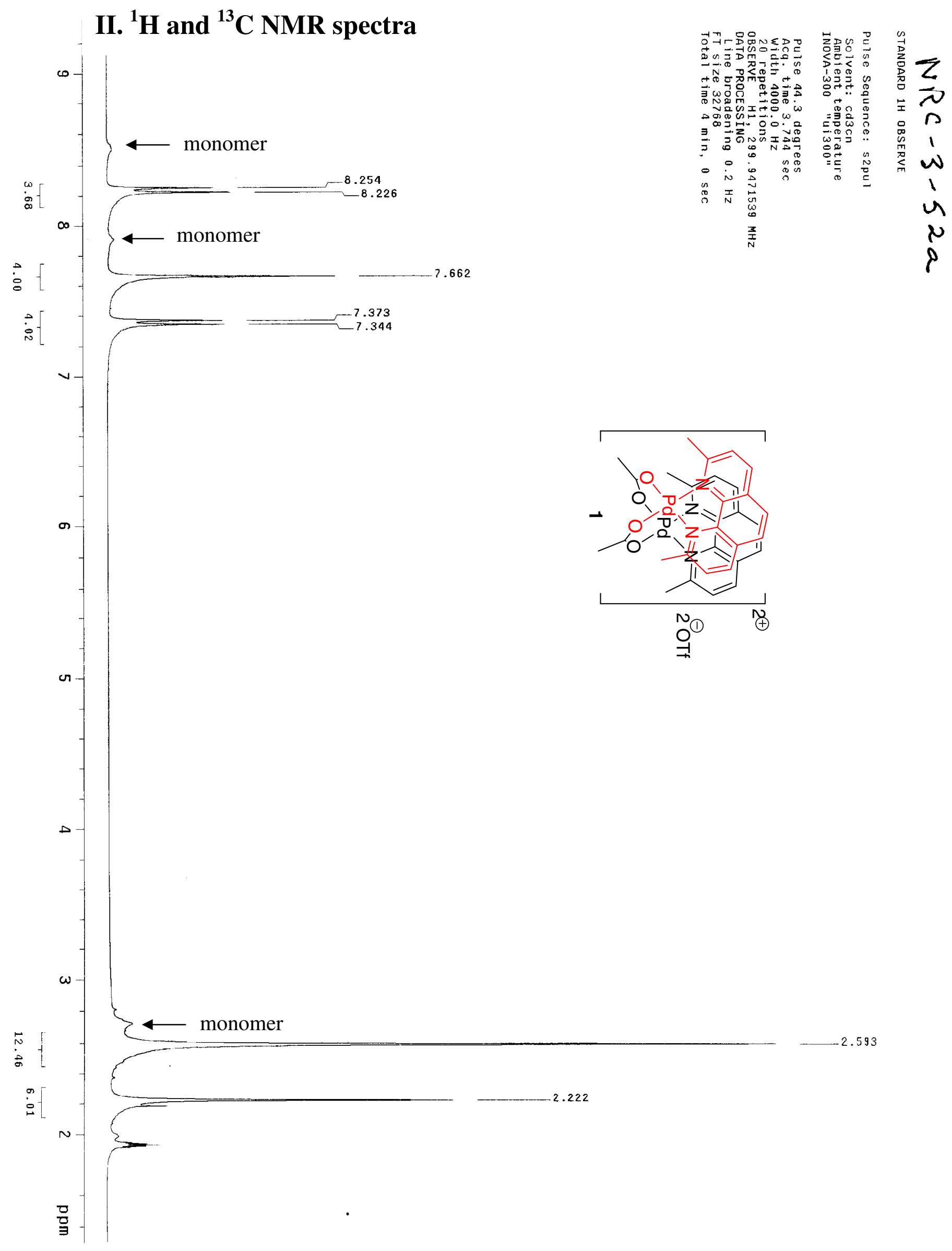




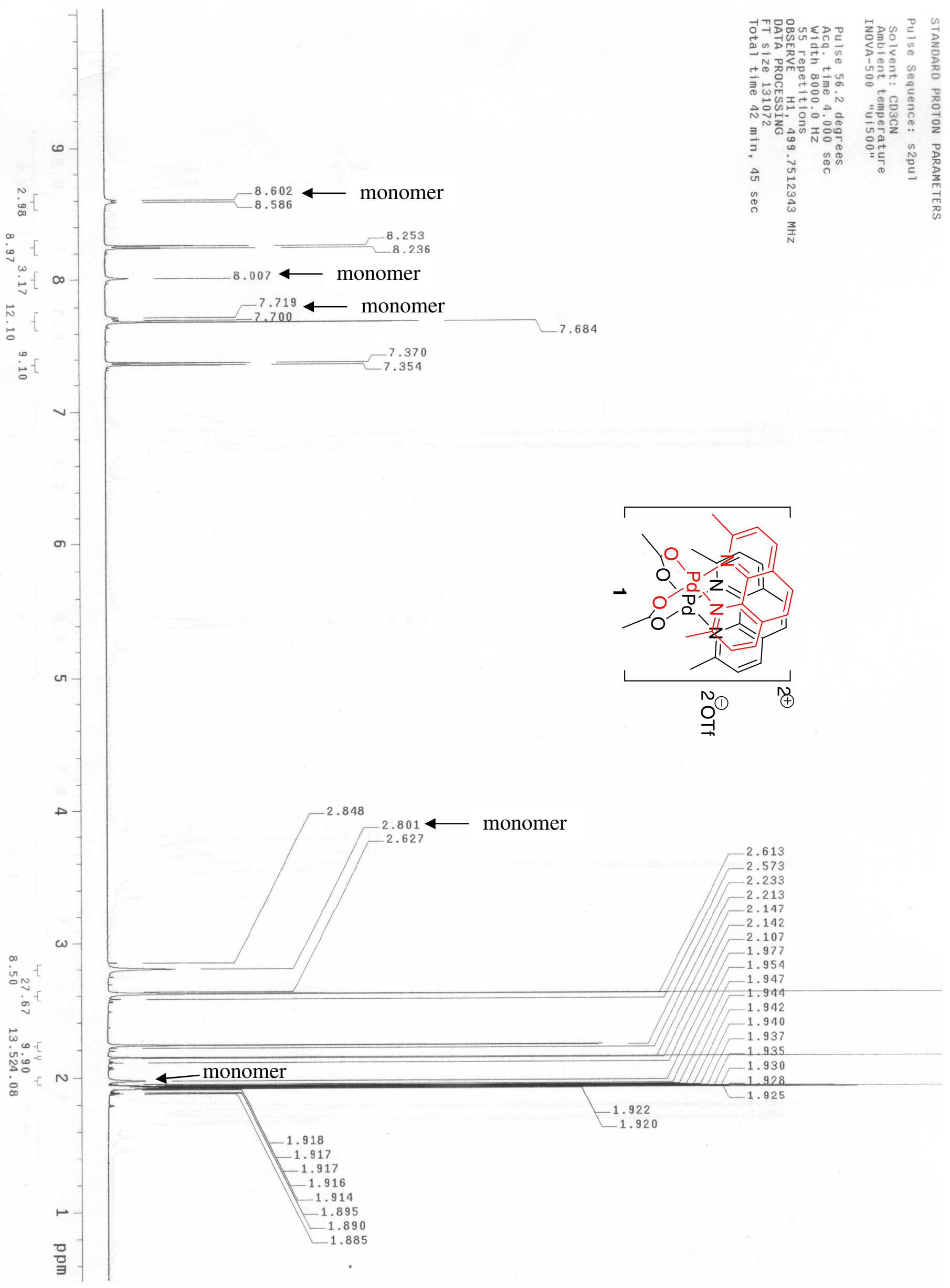



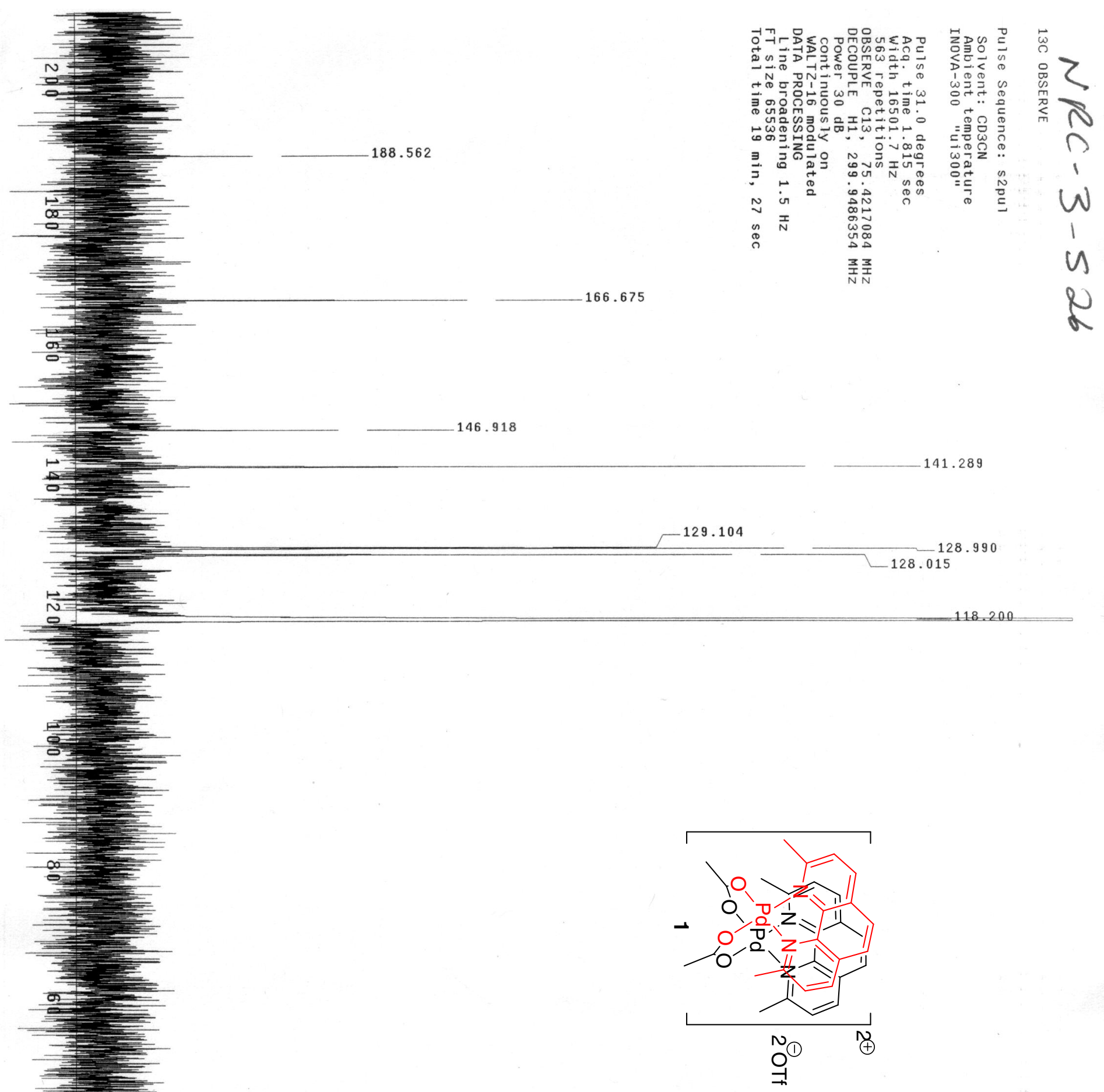

$-24.729$

$-2.000$

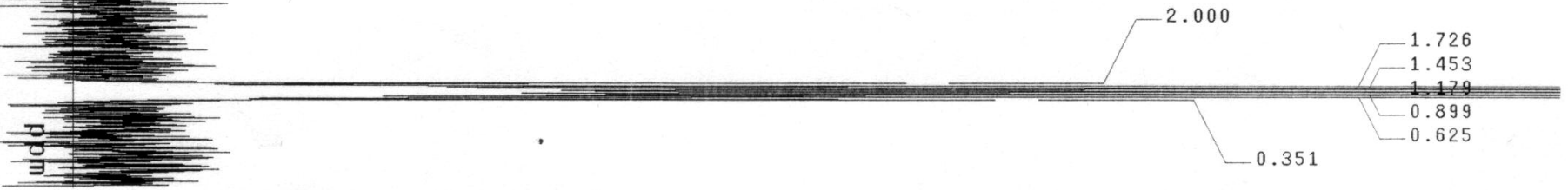




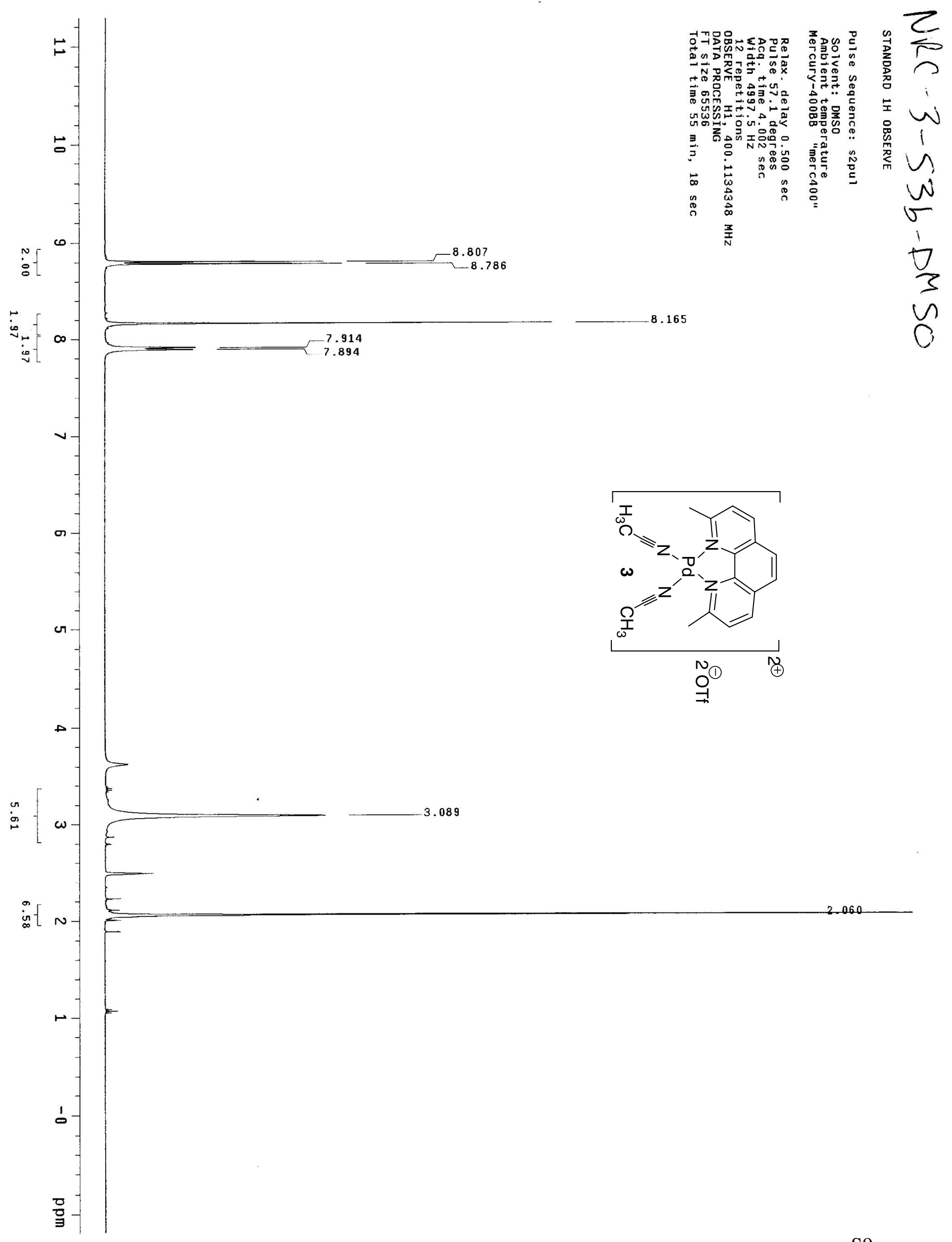




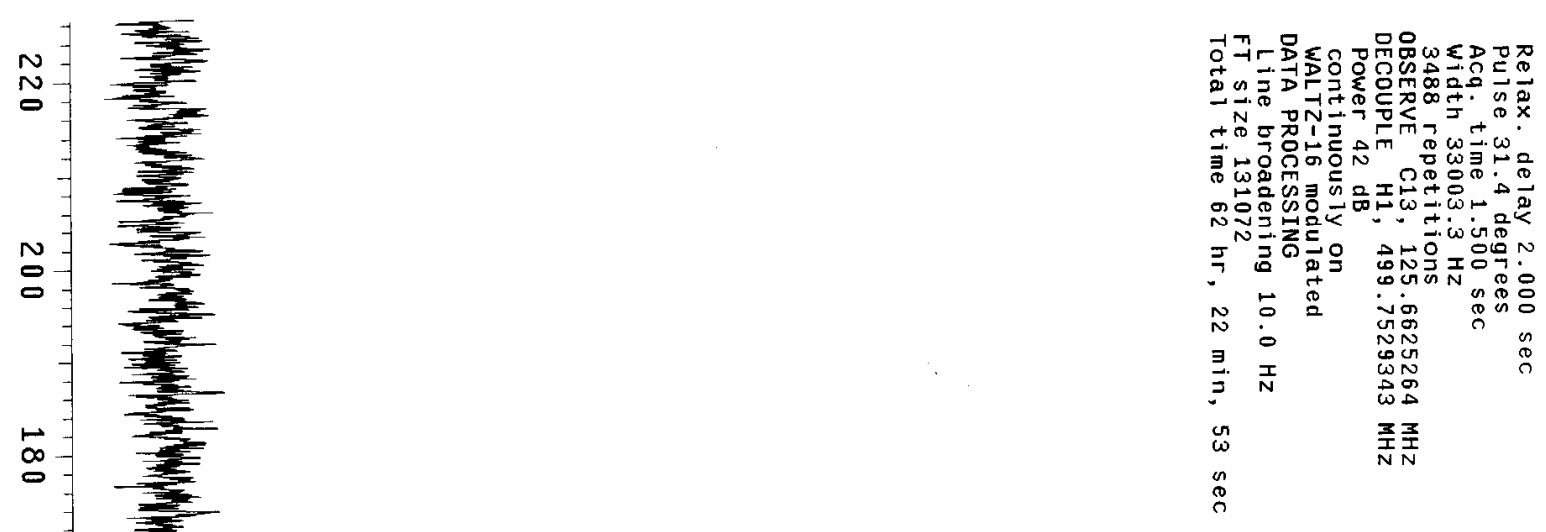

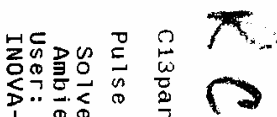

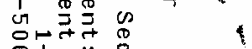

or.

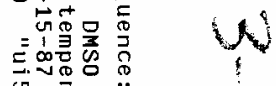

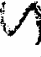

4

9

3

$-164.650$

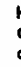

$=$

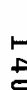

146.396

140.156
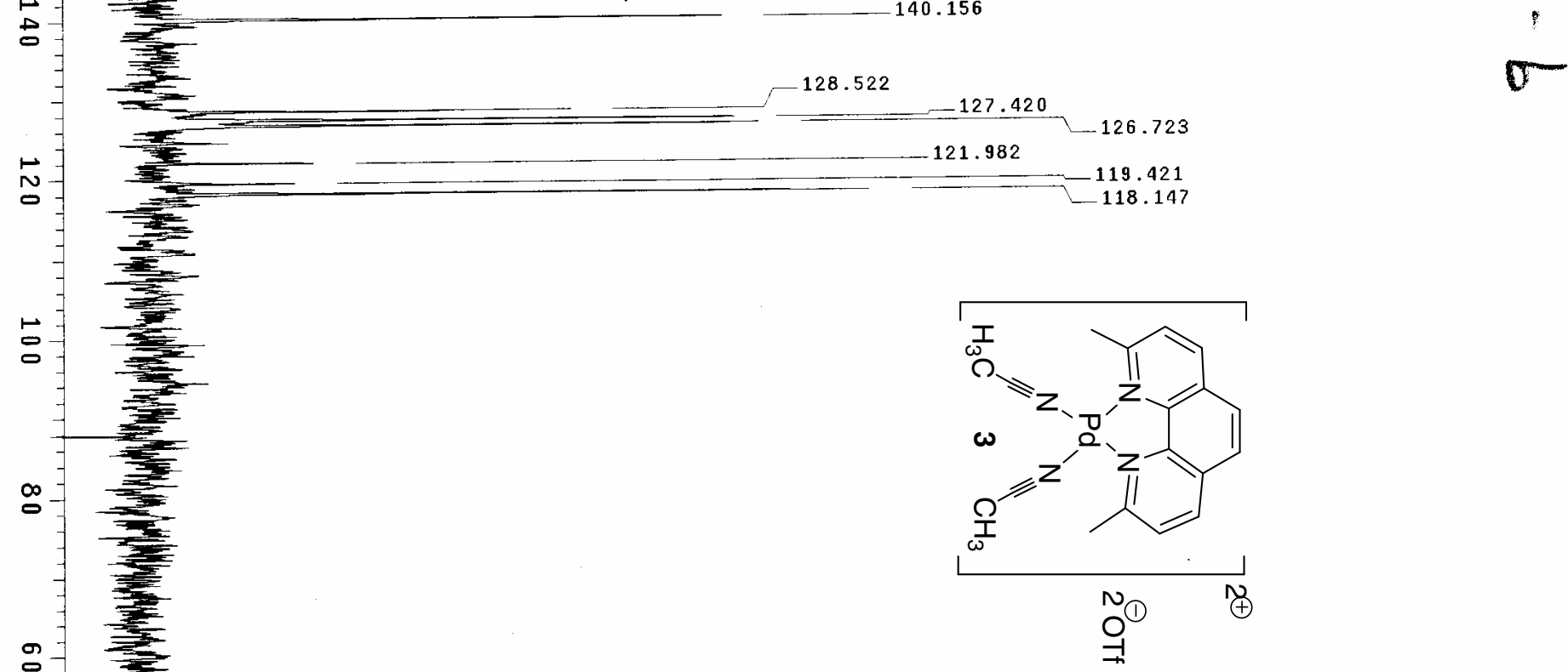

N

$-24.845$

$\circ$

188

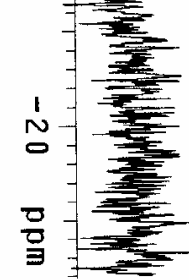




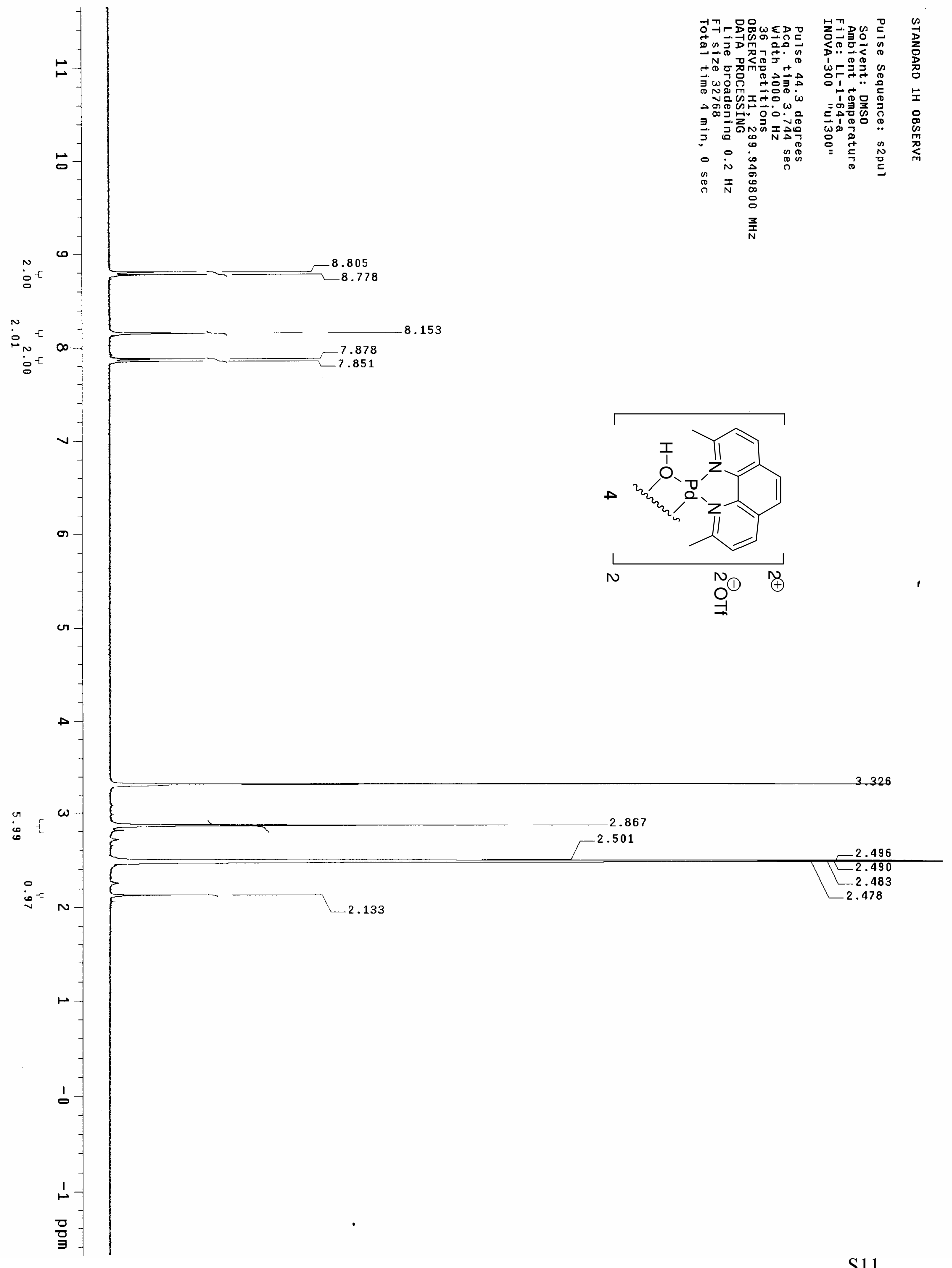




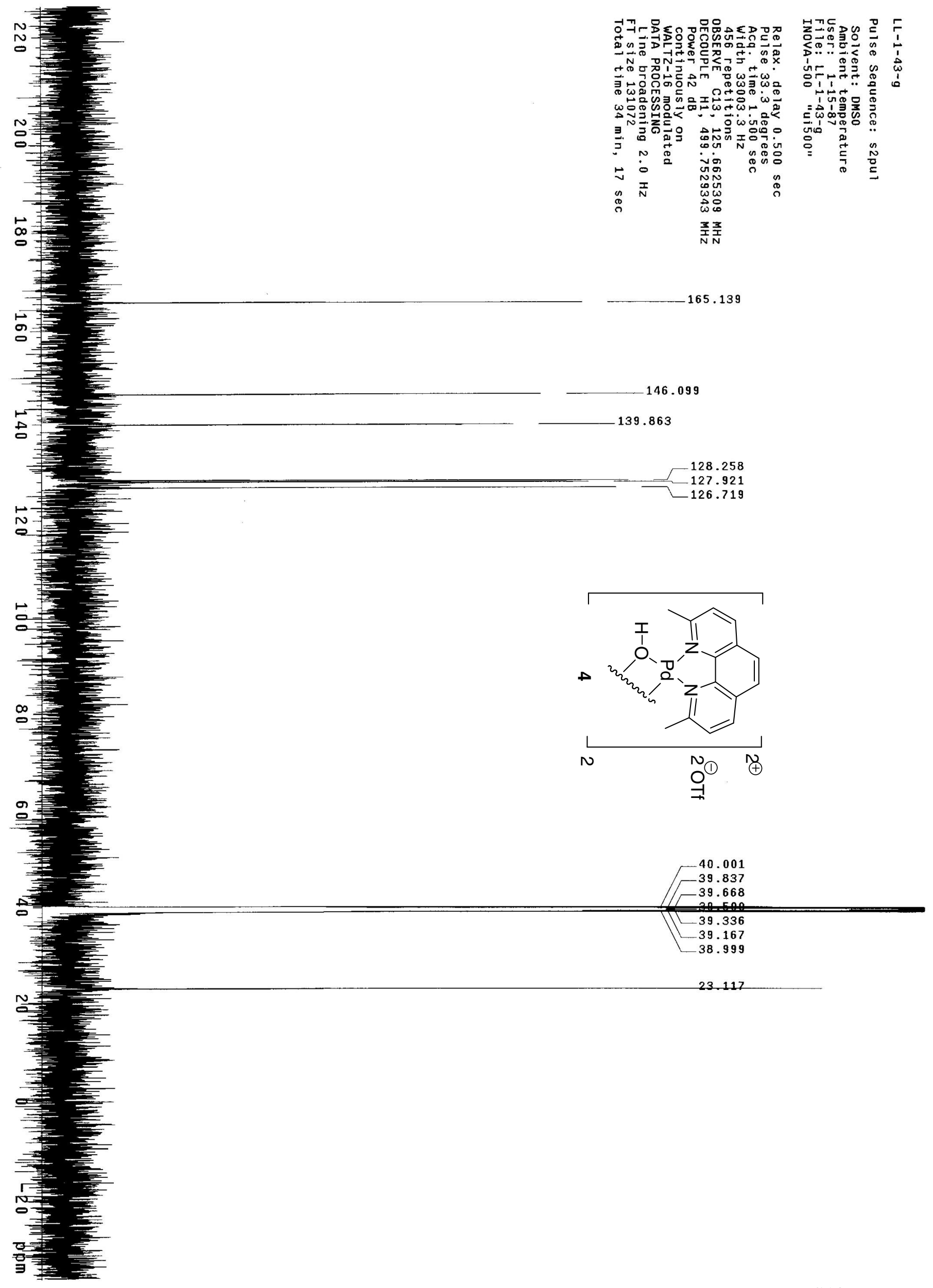




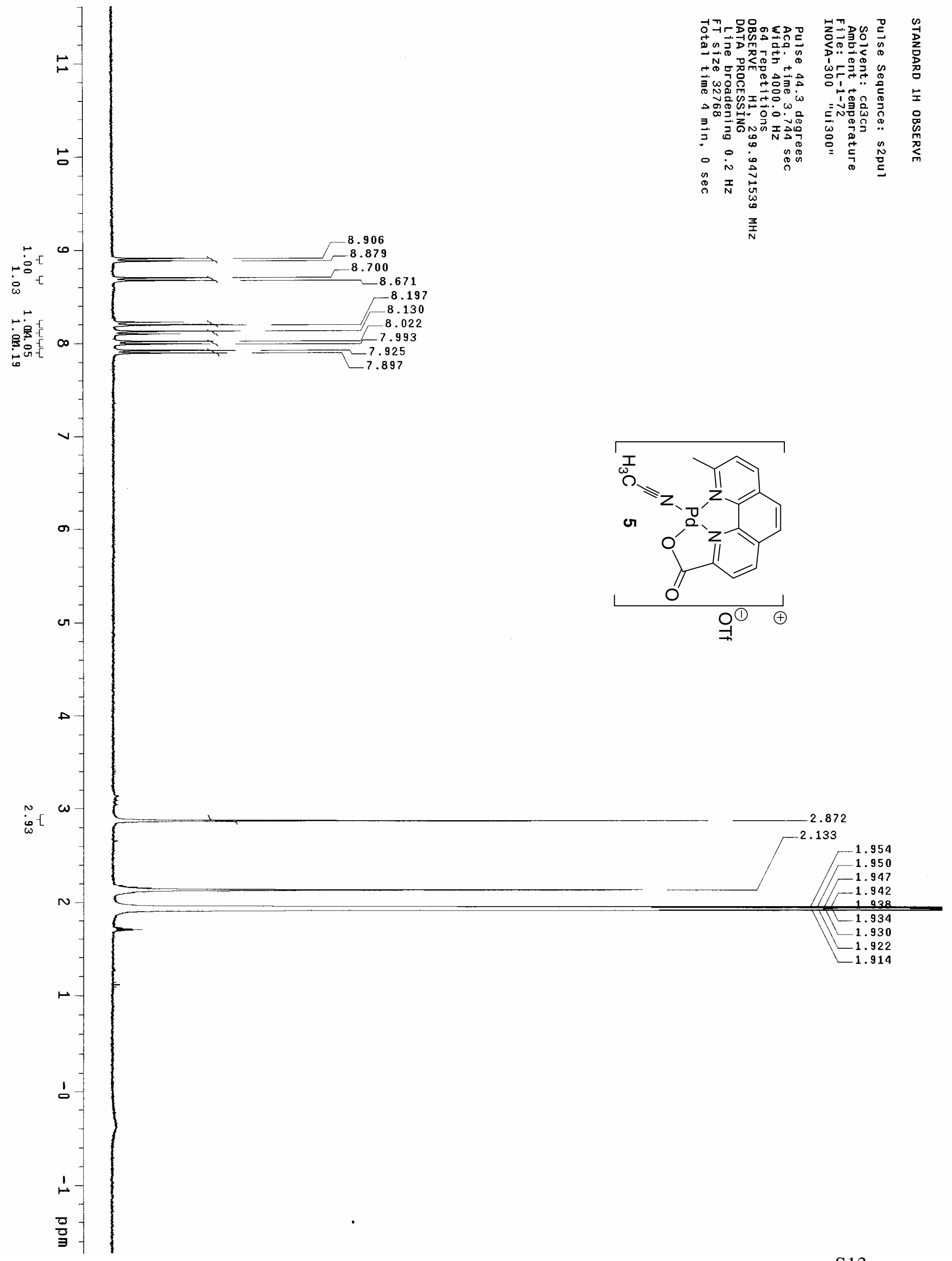




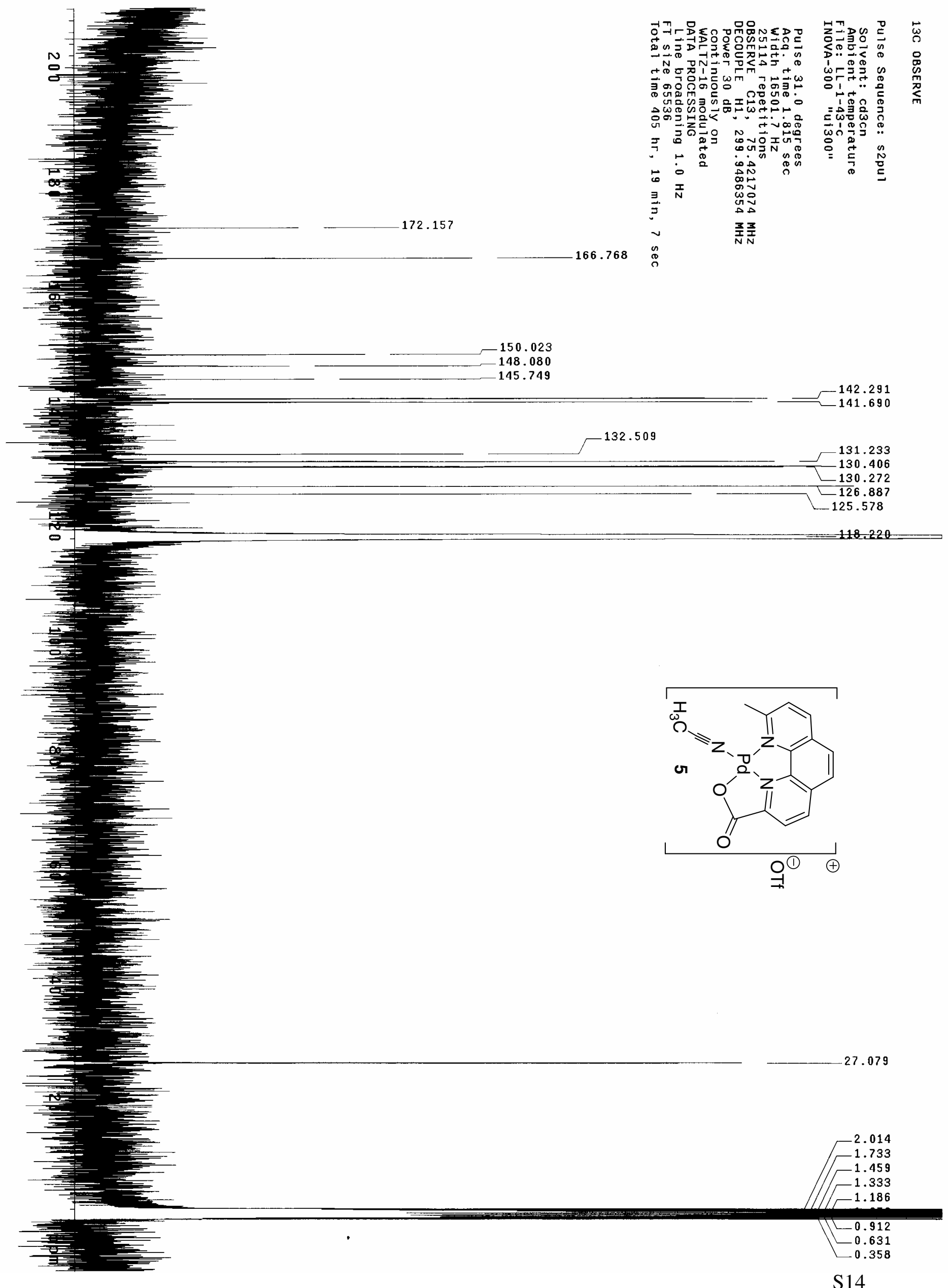




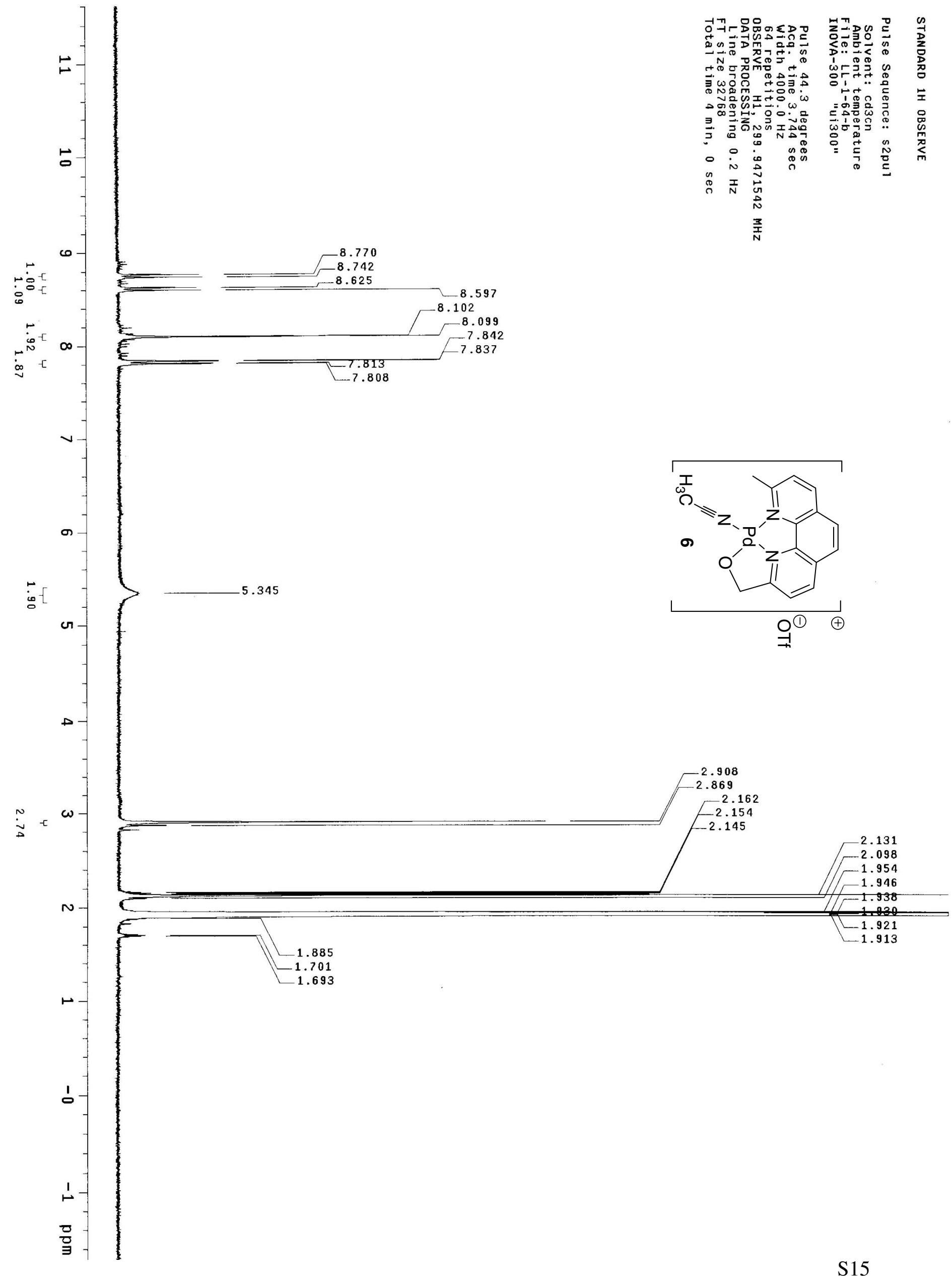




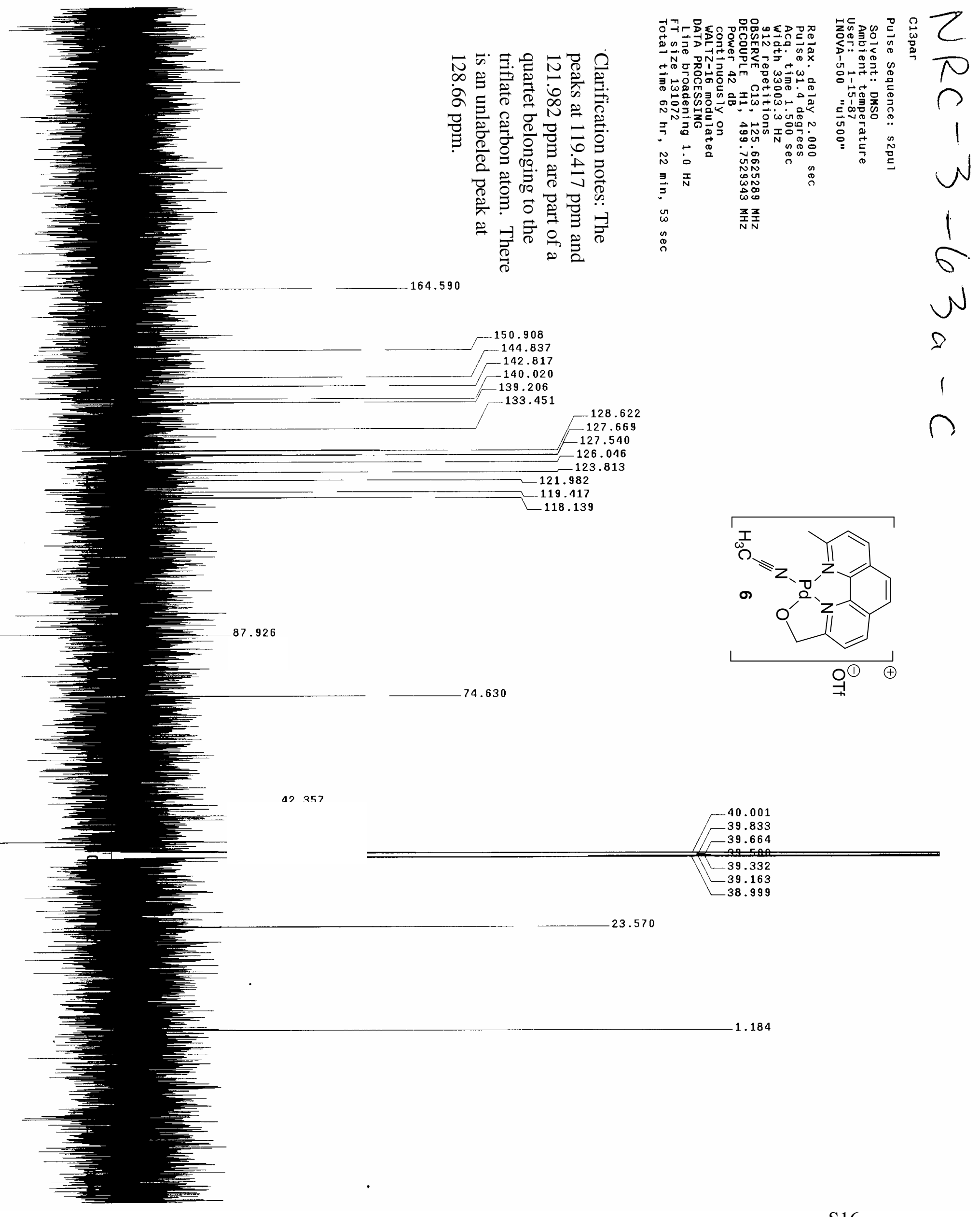




\section{Thermodynamic data for 1}

Table S1. Monomer and dimer concentrations determined by ${ }^{1} \mathrm{H}$ NMR in a 2.56 $\mathrm{mM}$ solution of $\mathbf{1}$ in acetonitrile- $d_{3}$ at various temperatures. Some decomposition occurs at higher temperatures, although monomer and dimer peaks could generally be resolved for integration.

\begin{tabular}{|c|c|c|c|}
\hline T (o C) & $\begin{array}{c}\text { Ratio of monomer:dimer } \\
\text { 1H NMR peak area }\end{array}$ & [monomer] (mM) & [dimer] (mM) \\
\hline 22 & 1 & 2.55 & 1.28 \\
\hline 34 & 1.44 & 3.01 & 1.05 \\
\hline 48 & 2.25 & 3.53 & 0.79 \\
\hline 62 & 3.23 & 3.89 & 0.61 \\
\hline 72 & 4.08 & 4.10 & 0.50 \\
\hline
\end{tabular}

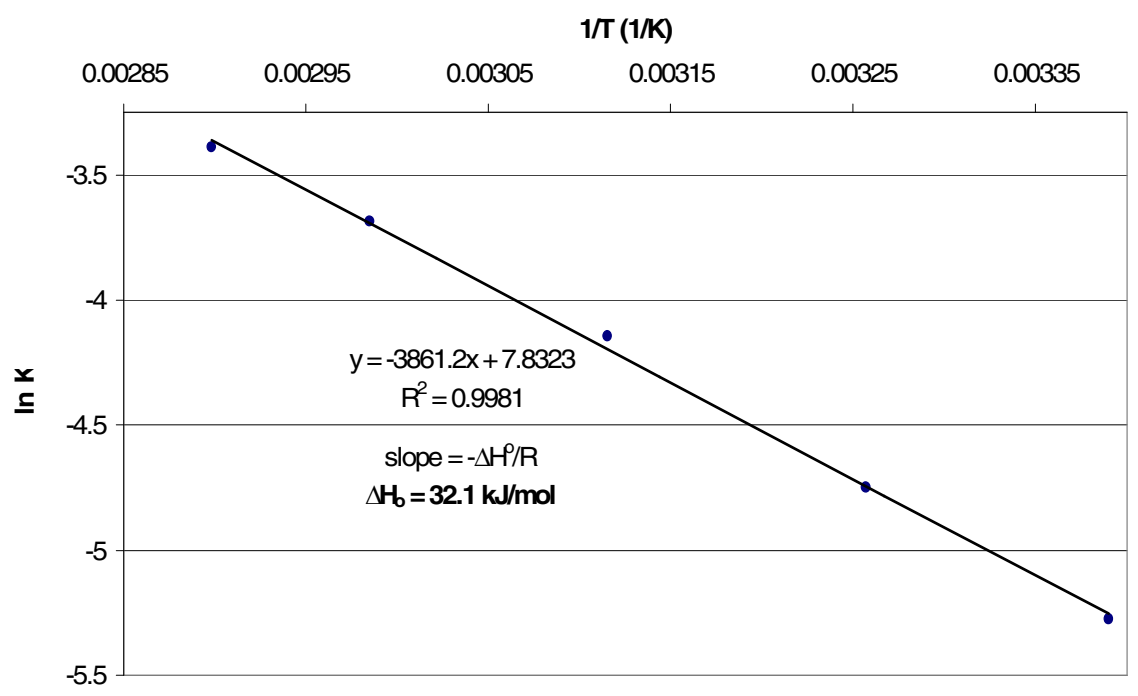

Figure S1. van't Hoff plot obtained from the monomer:dimer ratio at various temperatures as determined by ${ }^{1} \mathrm{H}$ NMR. The equilibrium constant $\mathrm{K}$ was calculated by $[\text { monomer }]^{2} /[$ dimer $]$.

Table S2. Calculated values for $\mathrm{K}, \Delta \mathrm{G}$, and $\Delta \mathrm{S}$ at various temperatures.

\begin{tabular}{|c|c|c|c|}
\hline $\mathrm{T}(\mathrm{K})$ & $\mathrm{K}(\mathrm{M})=[\mathrm{M}]^{2} /[\mathrm{D}]$ & $\Delta \mathrm{G}\left(\mathrm{J} \cdot \mathrm{mol}^{-1}\right)=-\mathrm{RT} \operatorname{lnK}$ & $\Delta \mathrm{S}\left(\mathrm{J} \cdot \mathrm{mol}^{-1} \mathrm{~K}^{-1}\right)=-[(\Delta \mathrm{G}-\Delta \mathrm{H}) / \mathrm{T}]$ \\
\hline 295 & 0.00510 & 12947 & 64.9 \\
\hline 307 & 0.00866 & 12119 & 65.1 \\
\hline 321 & 0.0159 & 11058 & 65.6 \\
\hline 335 & 0.0250 & 10274 & 65.2 \\
\hline 345 & 0.0336 & 9732 & 64.8 \\
\hline
\end{tabular}




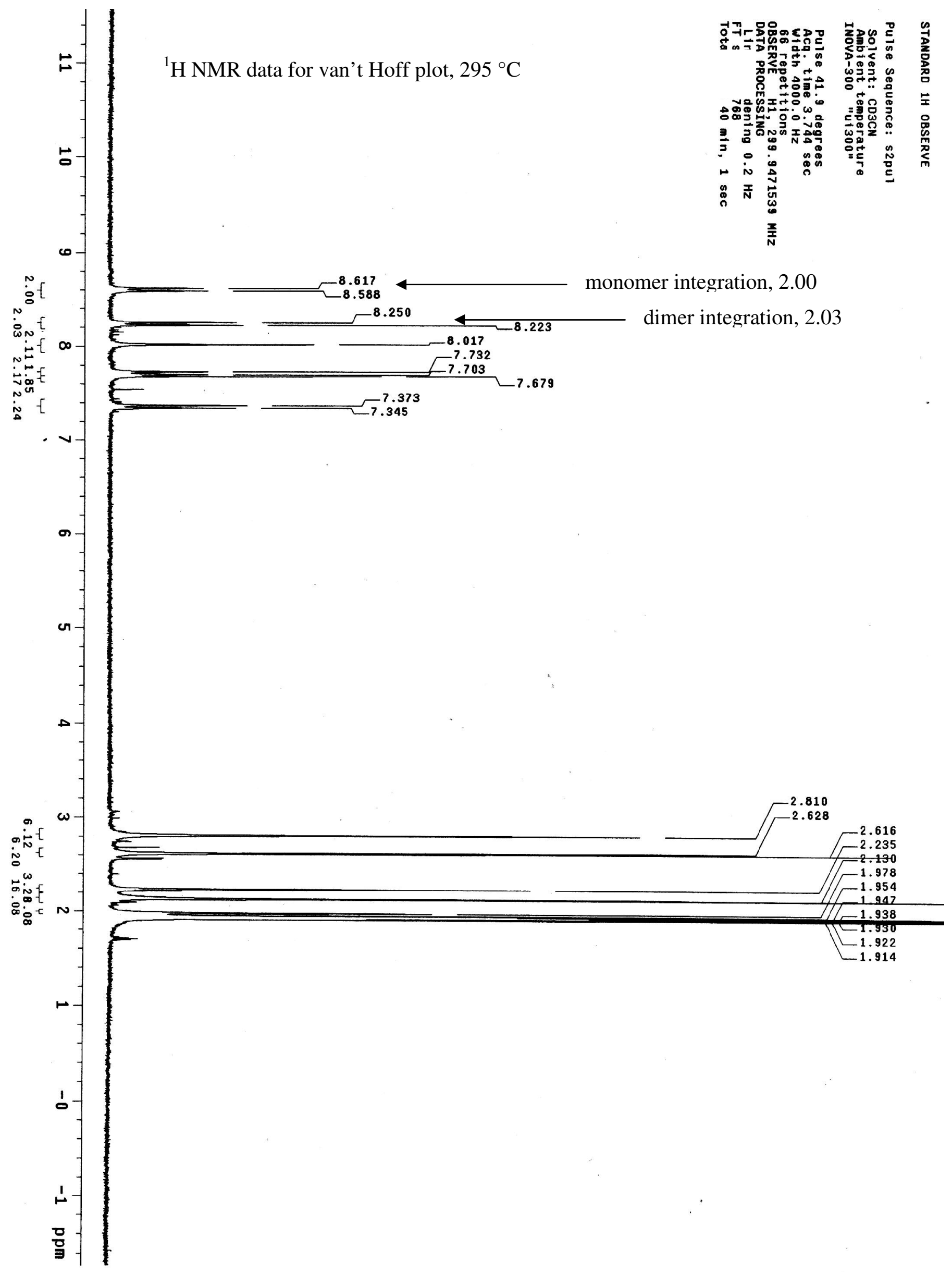




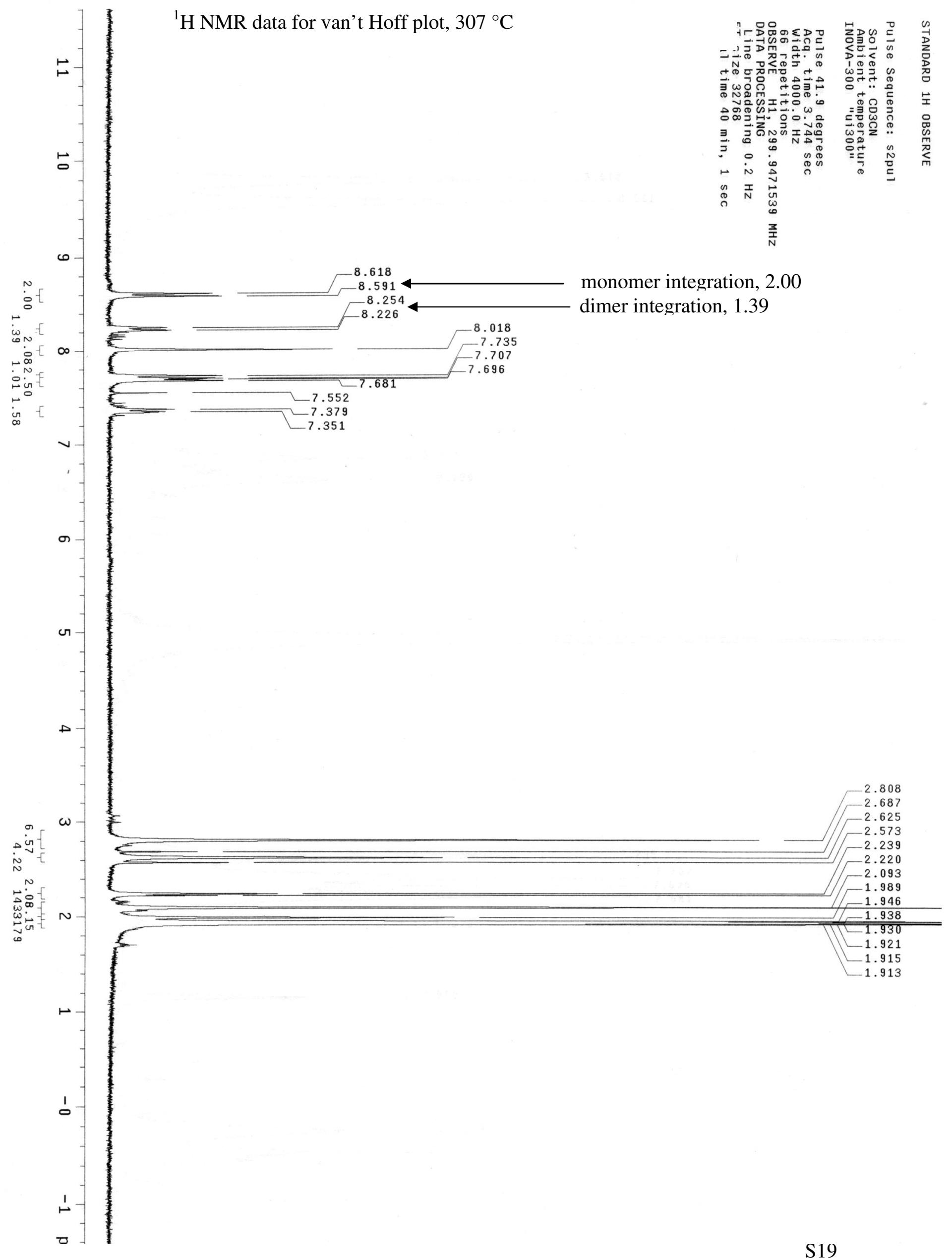



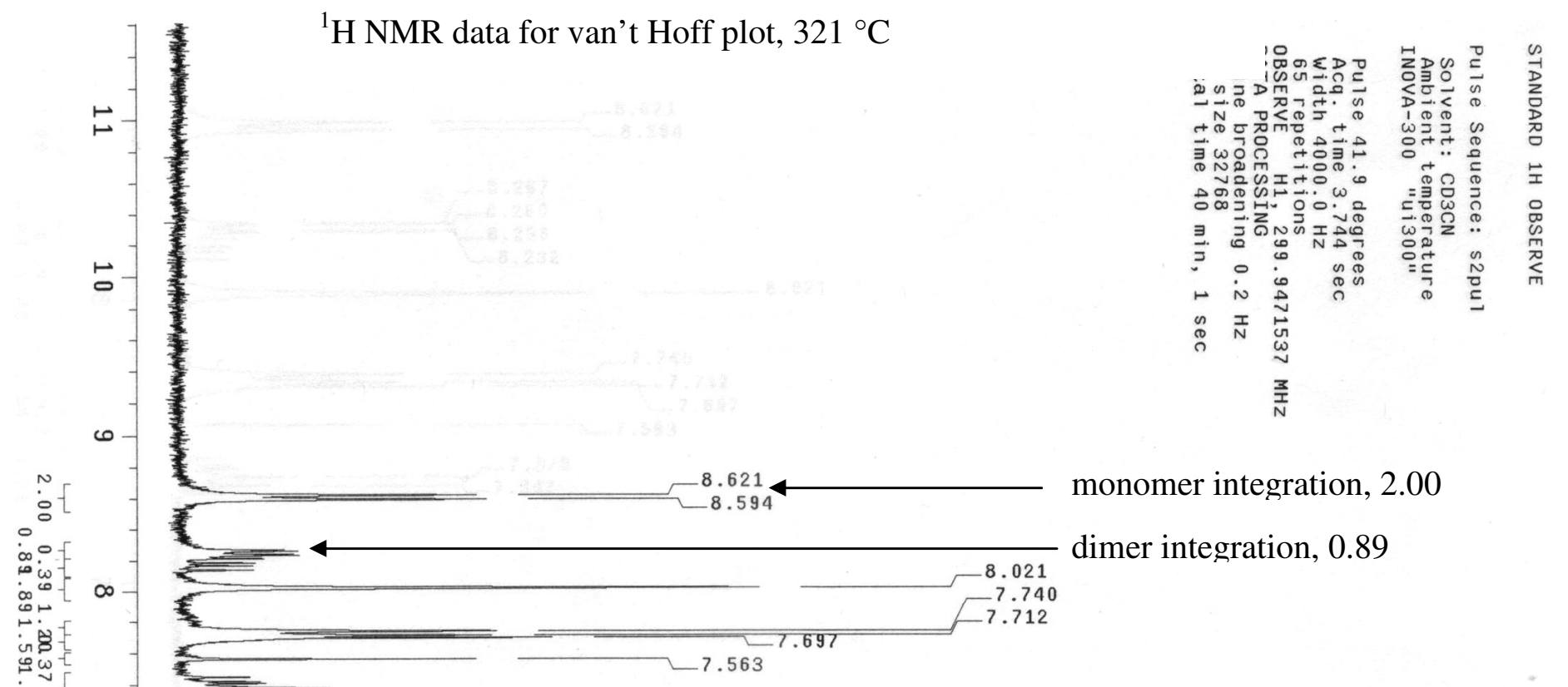

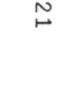




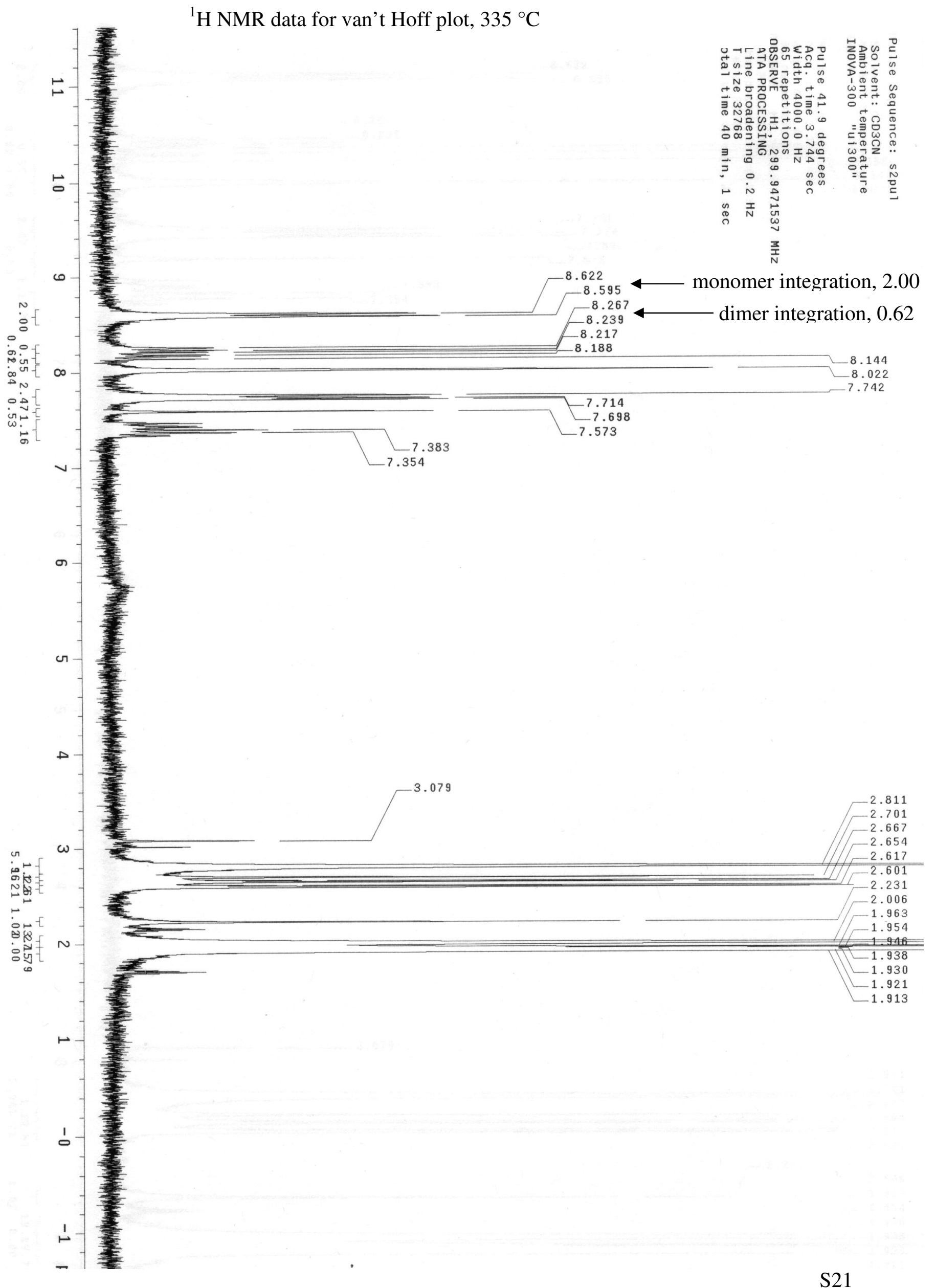




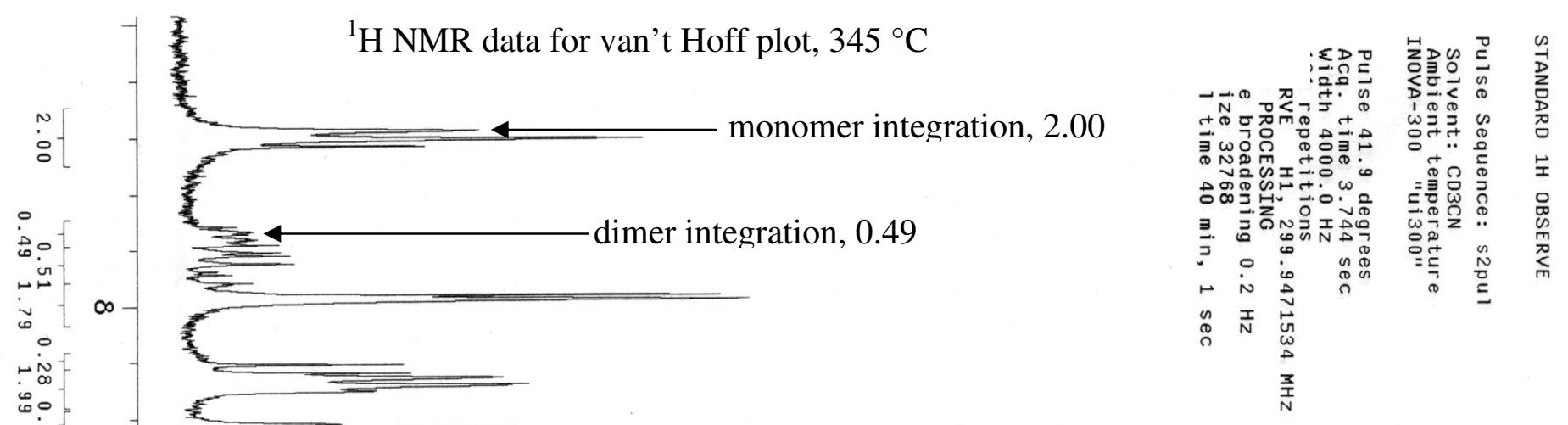

. 


\title{
IV. Electrochemical detection of hydrogen peroxide
}

\author{
General experimental details:
}

2-Heptanol, tetrabutylammonium triflate, and hydrogen peroxide (30\%) were purchased from Sigma-Aldrich and used without further purification. Acetonitrile was purchased from Fisher Chemical and used without further purification. Electrochemistry experiments were carried out with solutions of tetrabutylammonium triflate $(0.1 \mathrm{M})$ in acetonitrile $(10 \mathrm{ml})$ unless otherwise noted.

All electrochemical measurements were conducted with a $0.195 \mathrm{~cm}^{2} \mathrm{Pt}$-working electrode on a rotating disk. The electrode was cleaned by polishing with $0.05 \mu \mathrm{m}$ alumina in water on a felt cloth and sonicating for 2 minutes in water. $\mathrm{Ag} / \mathrm{AgNO}_{3}$ (sat'd) reference and a Pt-mesh counter electrode were employed. Cyclic voltammograms were acquired using a BioAnalytical Systems CV-50W potentiostat and Pine Instrument and a Pine Instrument Company ASR rotator.

\section{Determining a limit of detection for hydrogen peroxide:}

To estimate a limit of detection for hydrogen peroxide under conditions similar to those used in the aerobic oxidation of 2-heptanol, various amounts of hydrogen peroxide were added to standard solutions containing either 1 (3 mM) or 2-heptanol (200 mM), and cyclic voltammograms were recorded. Above a concentration of $0.5 \mathrm{mM}$ hydrogen peroxide in either solution, cyclic voltammograms showed a peak at approximately 1500 $\mathrm{mV}$ vs. NHE. Figure $\mathrm{S} 2$ shows examples at two different hydrogen peroxide concentrations.

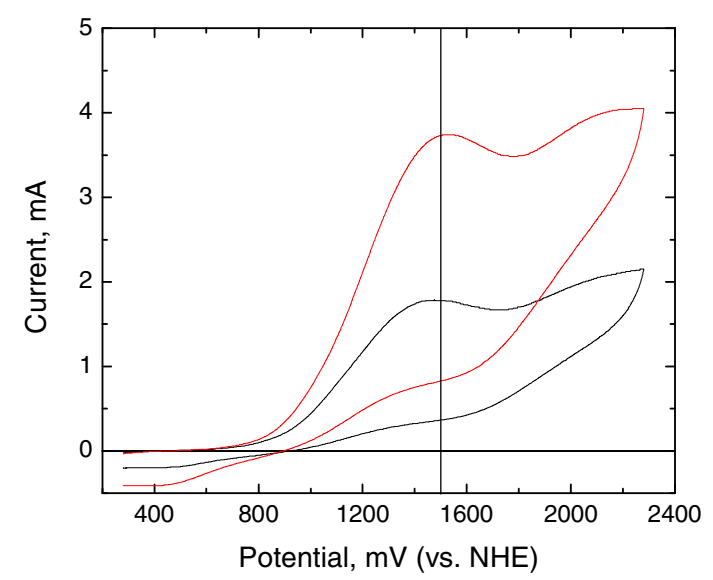

Figure S2. Cyclic voltammograms of $9.7 \mathrm{mM}$ (black) and $19.4 \mathrm{mM}$ (red) hydrogen peroxide in the presence of 2-heptanol. The vertical line denotes $1500 \mathrm{mV}$ vs. NHE.

Electrochemical monitoring of aerobic 2-heptanol oxidation for hydrogen peroxide:

To test for hydrogen peroxide evolution during the aerobic oxidation of 2heptanol, a $3 \mathrm{mM}$ solution of 1 was prepared (see general experimental details). The 
solution was stirred continuously using the rotating disk electrode (1600 rpm) and was constantly sparged with air. At $t=0,2$-heptanol was added ( $200 \mathrm{mM}$ final concentration) and current was monitored for $1200 \mathrm{~s}$ with the working electrode held at $+2100 \mathrm{mV}$ (Figure S3). No increase in current was observed over the time course of the experiment. Independent GC analysis showed a 2-heptanone yield of $13.5 \%$ during this interval. Addition of hydrogen peroxide at the end of the electrochemical experiment gave the characteristic peak, although the peak was shifted to $1200 \mathrm{mV}$ vs. NHE (Figure S4). A control experiment was also conducted using a solution of $3 \mathrm{mM} 1$ without 2-heptanol present and no current was observed when the electrode was held at $+2100 \mathrm{mV}$ (Figure S3).

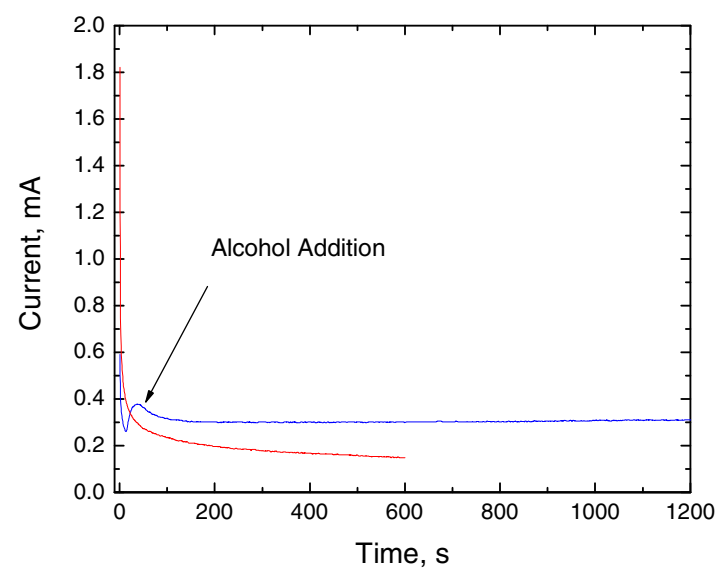

Figure S3. Current was measured in an aerated solution of 1 in the absence of 2-heptanol for $600 \mathrm{~s}$ (red) and in the presence of 2-heptanol for $1200 \mathrm{~s}$ (blue). The electrode was rotated at $1600 \mathrm{rpm}$ and held at $2100 \mathrm{mV}$ vs. NHE.

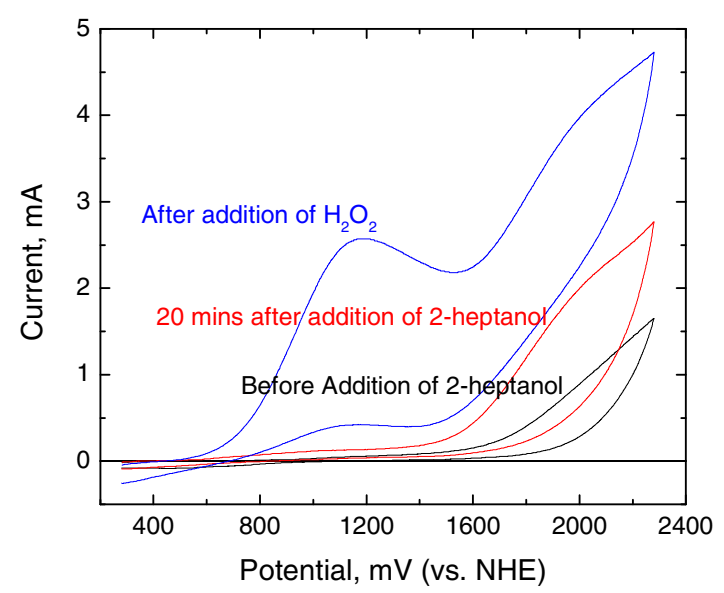

Figure S4. Cyclic voltammograms of the solution before addition of 2-heptanol (black), $1200 \mathrm{~s}$ after addition of 2-heptanol (red), and after addition of hydrogen peroxide (40 $\mathrm{mM})$ (blue). 


\section{Electrochemical monitoring of hydrogen peroxide decomposition by $\mathbf{1}$ :}

A $3 \mathrm{mM}$ solution of 1 was prepared and stirred using the rotating disk electrode. The potential was held at $+2100 \mathrm{mV}$ (vs. NHE) and the electrode rotated at $1600 \mathrm{rpm}$. Hydrogen peroxide (10 mM final concentration) was added and the current was monitored for $600 \mathrm{~s}$. Whereas little decrease in current was observed in the control solution with no catalyst, the catalyst solution exhibited a substantial decrease in the current (Figure S5) that could be fit to an exponential decay function, suggesting first order decay in $\mathrm{H}_{2} \mathrm{O}_{2}$. This experiment was repeated two more times with similar results.

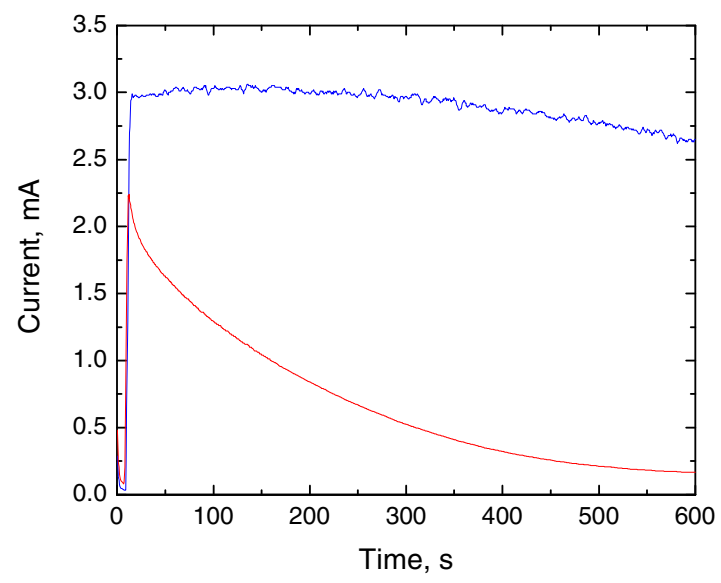

Figure S5. Electrochemical detection of $\mathrm{H}_{2} \mathrm{O}_{2}$ using a rotating disk electrode held at 2100 $\mathrm{mV}$ vs. NHE (blue) and its decomposition in the presence of $\mathbf{1}$ (red). 


\section{Conversion of $\mu$-hydroxo Pd dimer 4 to 1 using acetic acid}

$\mu$-Hydroxo Pd dimer 4 (5 mg, $0.005 \mathrm{mmol}$ ) was added to an NMR tube containing acetonitrile- $d_{3}\left(0.7 \mathrm{~mL}\right.$, sparingly soluble) and the ${ }^{1} \mathrm{H}-\mathrm{NMR}$ spectrum was recorded.

Immediately afterwards, a solution of acetic acid in acetonitrile- $d_{3}$ was added (1 eq. w.r.t. $\mathrm{Pd}, 60 \mu \mathrm{L}, 0.17 \mathrm{M}$ ). Additional equivalents of acetic acid were added (up to 8 equivalents w.r.t. Pd) and ${ }^{1} \mathrm{H}$ NMR spectra were recorded. After addition of 8 eq., the NMR tube was sonicated and the remaining solid reacted to give $\mathbf{1}$.

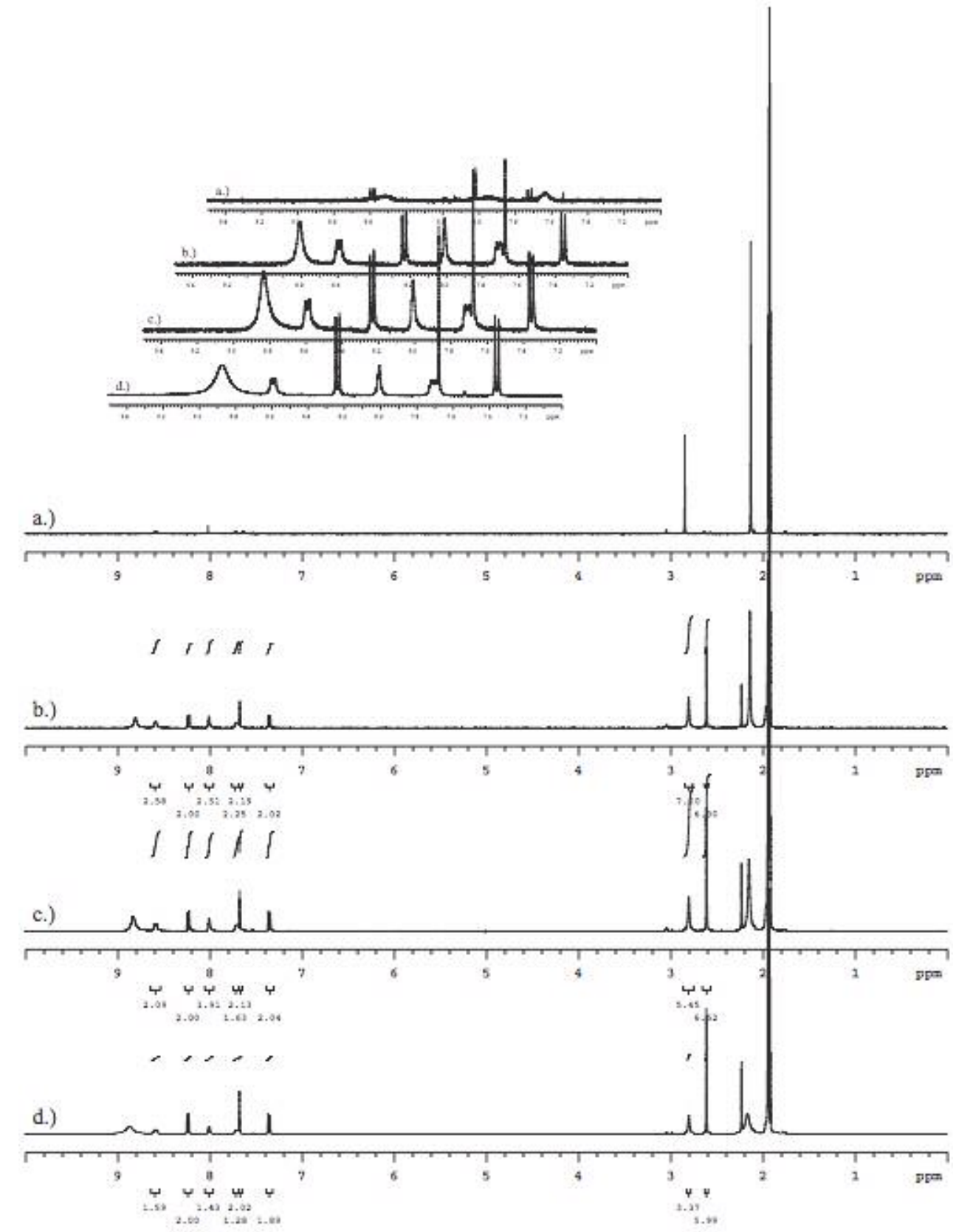

Figure S6. Conversion of $\mathbf{4}$ to $\mathbf{1}$ by addition of acetic acid; a.) before addition, b.) after addition of $\mathrm{AcOH}\left(1 \mathrm{eq} \cdot \mathrm{Pd}\right.$ atom $\left.^{-1}\right)$, c.) after addition of HOAc $\left(2 \mathrm{eq} \cdot \mathrm{Pd}\right.$ atom $\left.^{-1}\right)$, d. $)$ after addition of HOAc ( $4 \mathrm{eq} \cdot \mathrm{Pd}$ atom $\left.^{-1}\right)$. Inset: enlargement of the aromatic region for a-d. 


\section{Conversion of 1 to $\mu$-hydroxo Pd dimer 4 using water}

The dimeric compound 1 (10 mg, $0.0096 \mathrm{mmol})$ was dissolved in acetonitrile- $d_{3}$ $(0.7 \mathrm{~mL})$. Two drops of water were introduced to the NMR tube followed by vigorous shaking. More concentrated solutions of $\mathbf{1}$ can also be used; in this case, $\mathbf{4}$ can be isolated by precipitation, which will occur upon addition of water (up to a 1:1 wateracetonitrile mixture).

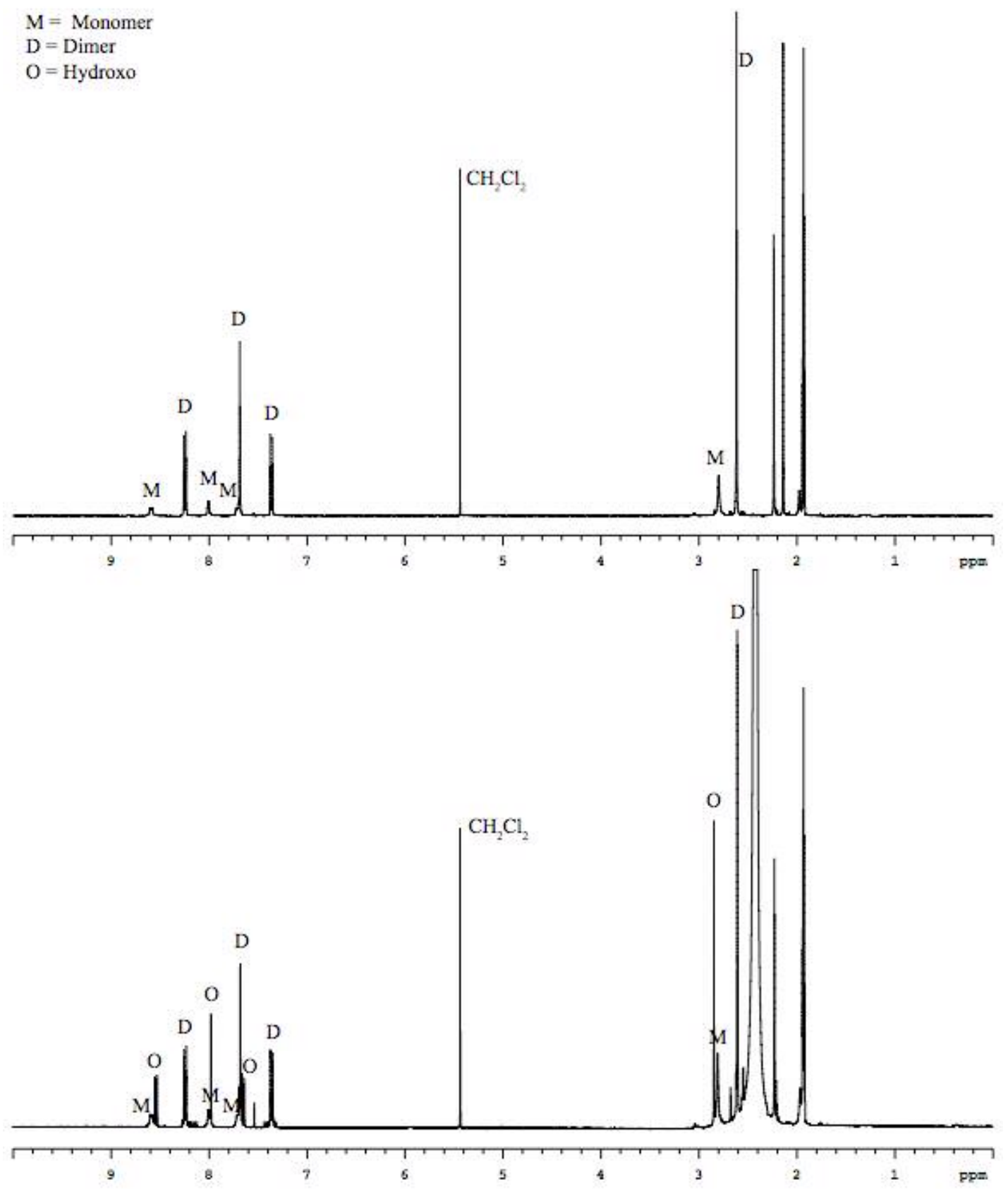

Figure S7. Formation of $\mathbf{4}$ by addition of $\mathrm{H}_{2} \mathrm{O}$ to $\mathbf{1}$; (top) $\mathbf{1}$ in acetonitrile; (bottom) after addition of 2 drops of $\mathrm{H}_{2} \mathrm{O}$. Peaks are labeled as specified in the legend. 


\section{References}

(1) ten Brink, G.-J.; Arends, I. W. C. E.; Hoogenraad, M.; Verspui, G.; Sheldon, R. A. Adv. Synth. Catal. 2003, 345, 1341.

(2) Sheldon, R. A.; Arends, I. W. C. E.; ten Brink, G.-J.; Dijksman, A. Acc. Chem. Res. 2002, 35, 774 . 